\title{
The European Union: A Comparative Perspective
}

\author{
Ernest A. Young*
}

This chapter, to be included in the Oxford Principles of EU Law volume, compares the federalisms of Europe and the United States. It argues that Europe can be sensibly viewed from both federal and intergovernmental perspectives, and that particular aspects of the European Union's structure fit each model. In particular, the EU is federal-that is, integrated to a comparable degree to the U.S. - with respect to its distribution of competences and the sovereignty attributed to EU law and institutions. But it is intergovernmental-that is, it preserves a center of gravity within the individual member states-with respect to the allocation of governmental capacity to enforce the law as well as to tax and spend, and also because Europeans continue to identify primarily with their member states.

The chapter also addresses two sets of questions about the EU's future. One concerns the possibility of "creeping centralization" that one observes in the United States, and which one might also detect in the EU's slogan of "ever closer union." I argue that any such tendency will be limited by the fact that the modern regulatory and welfare bureaucracies that have spurred centralization in the America instead developed at the member state level in Europe, prior to the advent of the EU. I also consider the impact of exogenous shocks, especially the euro crisis but also parallel crises over migration and terrorism. The response to these crises so far seems to have strengthened the EU's intergovernmental tendencies.

Comparing Europe and the United States can provide helpful insights about both systems-and federal systems in general. As is often true, the primary value of comparative law here is in the questions it raises, not the answers it may provide. Many aspects of federalism taken for granted in one system are considered nonobvious or even controversial in the other, and an appreciation of this fact can enrich federalism debates on both sides of the Atlantic.

\section{Table of Contents}

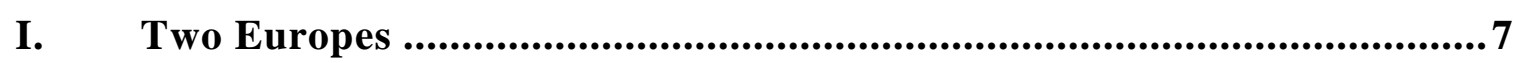

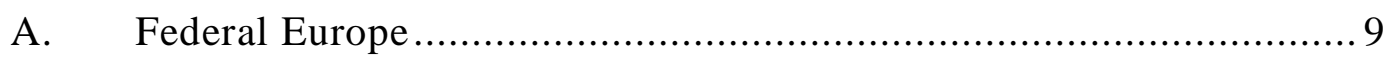

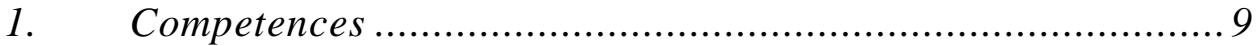

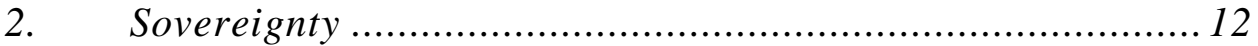

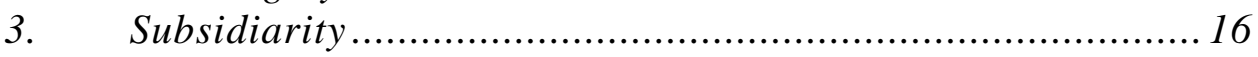

\footnotetext{
* Alston \& Bird Professor, Duke Law School, 219 Science Dr., Box 90362, Durham, NC 27708. young@law.duke.edu. I am grateful to Erin Delaney, Robert Schuetze, and participants at a University of Notre Dame Law School faculty workshop for helpful comments on the manuscript, and to Scott Anderson for valuable research assistance.
} 
4. Constitutionalism and the Democratic Deficit .................... 18

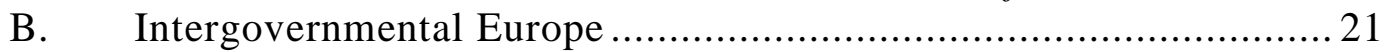

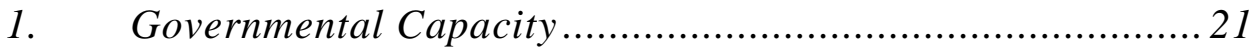

2. Administrative Capacity and Implementation .....................28

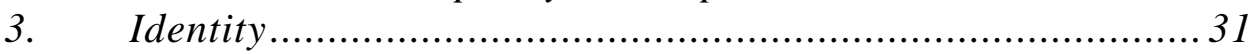

II. The Future of European Integration: Of Federalism and Time ...........38

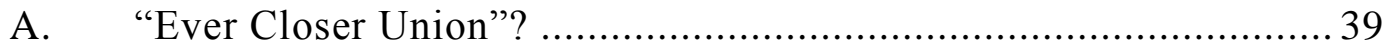

B. Shocks to the System: The Euro and Other Crises .......................... 46

1. Fiscal Federalism and Member State Sovereignty ............... 48

2. Variable Geometry and Intergovernmentalism ....................55

Conclusion

It is easy to be of two minds about Europe. From one perspective, the European Union enjoys an impressive array of legislative powers, and initiatives from the center account for a large and apparently increasing proportion of legislation within each Member State. Past efforts to contain the growth of the EU's authority - such as the principles of conferral and subsidiarity-have been disappointments. If the EU is in fact becoming a federal super-state, then two imperatives logically arise. Those who welcome this "ever closer union" nonetheless worry that it is insufficiently democratic and transparent, and that it lacks a public that identifies as European to hold it to account. ${ }^{1}$ And those who do not wish to be part of a European federal super-state start looking for limiting principles—or for the exits. ${ }^{2}$

A different perspective emphasizes the EU's institutional, functional, and political weaknesses. Despite the broad scope of its legislative mandate, the EU generally lacks authority or capacity to administer its laws directly; it employs a workforce equivalent to that of a city, not a continental economic superpower. It has minimal powers to tax and spend. And public opinion research makes clear that the vast majority of Europeans continue to primarily identify with their nation states-not the Union. These institutional and political realities have remained largely stable over time, despite round after round of treaty amendments and expansion of the EU to take in dozens of new members. From this perspective, the $\mathrm{EU}$ is the most successful international organization in human history, but it is a mistake to compare it to federal nation-states like the United States. ${ }^{3}$

\footnotetext{
${ }^{1}$ See, e.g., Jürgen Habermas, Democracy, Solidarity and the European Crisis, Social Europe J., July 5, 2013, available at http://www.social-europe.eu/2013/05/democracy-solidarity-and-theeuropean-crisis-2/.

${ }^{2}$ See, e.g., David Cameron, Speech on the European Union, Gov.UK, Jan. 23, 2013, available at https://www.gov.uk/government/speeches/eu-speech-at-bloomberg.

${ }^{3}$ See, e.g., Andrew Moravcsik, Europe Without Illusions, in Andrew Moravcsik, ed., Europe Without Illusions: The Paul-Henri Spaak Lectures, 1994-1999 3, 8 (2005).
} 
In part, these two perspectives reflect basic institutional compromises in the EU's architecture. At least since the Maastricht Treaty, the EU treaties have provided for "supranational" decisionmaking, along the lines of a federal state, in some areas such as the single market, with intergovernmental structures guaranteeing a veto or opt-out for individual member states in other areas, more closely tied to national sovereignty. ${ }^{4}$ The introduction of the Euro brought with it two additional compromises between intergovernmentalism and supranationalism. European Monetary Union (EMU) created supranational institutions to handle monetary policy, but the Member States retained sovereign control over fiscal policy, with disagreements to be worked out politically on an intergovernmental basis. And the EU's embrace of "variable architecture" allowed some nationsnotably, the United Kingdom and Denmark - not to participate in EMU at all. ${ }^{5}$

These two perspectives - federal and integovernmental-each have both a descriptive and a normative dimension. Each offers a lens for simply understanding what is happening in Europe. In this vein, each perspective focuses on different elements of the European legal and political order, and each points us toward a different set of comparators and evaluative criteria. Each perspective also, however, represents normative aspirations for Europe. As Alberto Alesina and Roberto Perotti have observed, "an unresolved tension between those who would like the European Union to evolve into a super national entity (the federalists or super nationalists) and those who would like it to stay a union of independent governments (the intergovernmentalists) has shaped much of the history of European institutions." 6

The debate, moreover, is not simply academic. The "Convention on the Future of Europe," which set out twelve years ago to draft a constitutional treaty, was at least partially driven by the idea that Europe was becoming a federal state. Although the resulting constitutional treaty failed, the Member States adopted its institutional core - somewhat more quietly-in the Treaty of Lisbon. On the other hand, the German Constitutional Court accepted the legality of the Lisbon Treaty only because it concluded that the EU remained an essentially intergovernmental

\footnotetext{
${ }^{4}$ See generally Sergio Fabbrini, The Euro Crisis and Its Constitutional Implications, in Serge Champeau, Carlos Closa, Daniel Innerarity, \& Miguel Poaires Maduro, eds., The Future of Europe: Democracy, Legitimacy and Justice after the Euro Crisis, 19, 20-21 (2015) (discussing the Maastricht Treaty's compromise between intergovernmentalism and supranationalism in different policy areas).

${ }^{5}$ See id. at 22-26.

${ }^{6}$ Alberto Alesina \& Roberto Perotti, The European Union: A Politically Incorrect View, $18 \mathrm{~J}$. Econ. Perspectives 27, 27 (Fall 2004).

${ }^{7}$ See Russell Miller, Germany vs. Europe: The Principle of Democracy in German Constitutional Law and the Struggle for European Integration, Washington \& Lee Public Legal Studies Research Paper Series No. 2013-14, Aug. 13, 2013, at 3 n. 9 (noting that "[a] European federal state was the undeniable ambition of the advocates for a European constitution"). But see Joseph Weiler, Editorial: Marking the Anniversary of the Universal Declaration; The Irish No and the Lisbon Treaty, EJIL: Talk!, Dec. 9, 2008, available at http://www.ejiltalk.org/letters-to-theeditor-respond-to-ejil-editorials-vol-194/ (arguing that what the Convention actually produced was merely "a Reform Treaty adapting the European Union to enlargement").
} 
entity; ${ }^{8}$ as the Court put it, "the Treaty of Lisbon decided against the concept of a European federal state." 9 How one thinks of the EU thus has important consequences for its current legality and imperatives for reform.

Europe's responses to a series of recent crises are likely to put pressure on its present uneasy compromise between federalism and intergovernmentalism. Responses to the Euro crisis have taken the form of agreements among the Euro countries, operating outside the ordinary EU lawmaking process, and they have sanctioned an unpecedented intrusion into the Member States' fiscal affairs. ${ }^{10}$ Even as the governments of the Euro nations draw closer together pursuant to these agreements, backlashes against austerity in the more financially-troubled Member States threaten the Euro area's unity. ${ }^{11}$ That unity is also under threat from Europe's most massive migration crisis since the Second World War. The sheer size of the migrant wave put significant pressure on the Member States' ability to agree on how many immigrants each should absorb, and the pressure has increased signficantly as the migration issue became linked to fears of terrorism in the wake of the Paris attacks in November of $2015 .^{12}$

The juxtaposition of the federalist and intergovernmental perspectives on Europe can tell us something about how federal systems work-both in their incremental evolution over time and in their response to crisis. In America, constitutional debate tends to focus on the scope of national legislative power. In the recent litigation over President Obama's sweeping national healthcare reform, the issue that drew most of the attention was whether Congress's power to regulate commerce among the several states extended to a requirement that all individuals purchase health insurance. ${ }^{13}$ Yet Americans probably focus on the scope of national regulatory jurisdiction because we take for granted the national government's institutional authority and capacity to tax, spend, and enforce national law. Europe gives us a window on the relative importance of these

\footnotetext{
${ }^{8}$ Lisbon Treaty Case, 123 BVerfG 267 (2009); EFSF Case, 129 BVerfGE 124 (2011), available at http://www.bverfg.de/entscheidungen/es20090630_2bve000208en.html.

${ }^{9}$ Id. at $370-71$.

${ }^{10}$ See generally Federico Fabbrini, Economic Governance in Europe: Comparative Paradoxes, Constitutional Challenges (forthcoming 2016).

${ }^{11}$ See, e.g., Barry Hatton, Portuguese Lawmakers Force Government to Resign by Rejecting Its Austerity Policies, U.S. News \& World Report, Nov. 10, 2015, available at http://www.usnews.com/news/business/articles/2015/11/10/portugal-braces-for-fall-of-govt-amidausterity-backlash; Ambrose Evans-Pritchard, Greek Deal Poisons Europe as Backlash Mounts Against 'Neo Colonial Servitude', The Telegraph, July 13, 2015, available at http://www.telegraph.co.uk/finance/economics/11737388/Greek-deal-poisons-Europe-asbacklash-mounts-against-neo-colonial-servitude.html.

${ }^{12}$ See, e.g., Holly Ellyat, After Paris Attacks, Is there a EU Backlash Against Migrants?, CNBC, Nov. 27, 2015, available at http://www.cnbc.com/2015/11/27/paris-attacks-turn-eu-leadersagainst-migrants.html; After Paris, Drawbridges Up?, The Economist, Nov. 21, 2015, available at http://www.economist.com/news/europe/21678832-schengen-system-open-borders-was-alreadyunder-pressure-latest-terrorist-attacks-may.

${ }^{13}$ See Nat'l Fed'n of Indep. Bus. v. Sebelius, 132 S. Ct. 2566 (2012).
} 
capacities, and that may in turn encourage American judges and scholars to refocus on under-appreciated limits on those capacities in the U.S. system.

Likewise, European debates about national and European identity ought to remind Americans of identity's central role in multi-level systems. In Europe, Member State identities remain both primary and powerful, ${ }^{14}$ and they may impose significant constraints on certain sorts of EU-level policies-especially those that call on citizens of some Member States to make economic sacrifices on behalf of others. ${ }^{15}$ Most scholars of American federalism, on the other hand, assume that no meaningful state-level attachments exist in this country. ${ }^{16}$ This, of course, is an assumption about an empirical fact, and it may well be incorrect. ${ }^{17}$ But Europe's debates about identity can illumine both the ways that empirical question might be answered and the consequences of that answer for the federal balance.

Comparisons are always difficult, of course, and the European Union remains terra incognita to most American legal scholars. That is understandable, perhaps - the domestic literature, particularly in constitutional law, is vast enough, and the EU regime is both intimidatingly complex and seemingly in constant flux. ${ }^{18}$ This is particularly true on the structural side of constitutional law. As one of our finest comparative constitutionalists observed some years ago, a federal structure "typically constitutes an interrelated 'package of arrangements. No one element of the package can be compared to a similar-seeming element in a different federal system without more broadly considering the comparability of the whole 'package' and the role of the particular element within that federal package."19 This makes it hard to feel like one understands anything without

\footnotetext{
${ }^{14}$ See, e.g., Neil Fligstein, Euro-Clash: the EU, European Identity, and the Future of Europe 4 (2008); Peter J. Katzenstein \& Jeffrey T. Checkel, Conclusion-European Identity in Context, in Jeffrey T. Checkel \& Peter J. Katzenstein, eds., European Identity 213, 215 (2009) ("The number of unambiguously committed Europeans (10-15\% of the total population) is simply too small for the emergence of a strong cultural European sense of belonging.").

${ }^{15}$ See, e.g., Amitai Etzioni, EU: Closing the Community Deficit, 43 Intereconomics 324, 327 (2008).

${ }^{16}$ See, e.g., Malcolm M. Feeley \& Edward Rubin, Federalism: National Identity and Tragic Compromise 115-23 (2008); Robert A. Schapiro, Polyphonic Federalism: Toward the Protection of Fundamental Rights 27 (2009).

17 See Ernest A. Young, What Does It Take to Make a Federal System? On Constitutional Entrenchment, Separate Spheres, and Identity, 45 Tulsa L. Rev. 831, 841-42 (2010) (book review).

${ }^{18}$ The institutional architecture of the EU has, for example, changed significantly in the fourteen years since my last effort to compare European and American federalism. See Ernest A. Young, Protecting Member State Autonomy in the European Union: Some Cautionary Tales from American Federalism, 77 N.Y.U. L. Rev. 1612 (2002).

${ }^{19}$ Vicki C. Jackson, Narratives of Federalism: Of Continuities and Comparative Constitutional Experience, 51 Duke L.J. 223, 273-74 (2001).
} 
understanding everything. American scholars' focus on their own country is not so much arrogance (as others often assume) but the better part of valor. ${ }^{20}$

To the complexity of current comparisons we must also add the element of time. American scholars who care about federalism confront a history of the relentless expansion of national power. Assessing whether a similar future awaits the EU, however, requires consideration of the centralization dynamic in relation to other historical arcs. The growth of national power in America occurred in tandem with the development of the modern regulatory and welfare state. Indeed, one way to tell that story is that the tardy growth of modern governance at the state level opened the door for those institutions to flower at the national level. ${ }^{21}$ In Europe, by contrast, the regulatory welfare state developed and is firmly entrenched within each Member State, and any effort to shift those core responsibilities to Brussels would likely confront the same inertial forces that, in America, impede devolution of national authority to the states.

The element of time, however, requires attention not only to long-term historical processes but also to shocks and crises that may destabilize existing arrangements. American federalism, after all, has been profoundly shaped by crises like the Civil War and the Great Depression. Similarly, Europe's present equilibrium is already under pressure from the "Great Recession" of the last few years and the accompanying debt and banking crises in Greece, Portugal, Ireland, and other EU Member States. ${ }^{22}$ These pressures have been compounded, even more recently, by a migration crisis involving unprecedented refugee flows from the Middle East and a renewal of terrorist attacks on European soil. Each of these crises has exacerbated the tensions between federalism and intergovernmentalism in EU governance.

This essay focuses on comparisons between America and Europe with respect to questions of constitutional structure. ${ }^{23}$ I begin, in Part I, with the two contradictory perspectives on the EU's federal balance that I have already mentioned. I discuss the variables affecting the degree of actual centralization in Europe and what those variables can tell us about federalism in the United States. Part II tries to put those variables in comparative historical context. I suggest that the late advent of the EU, relative to the development of modern governance in the Member States, may dampen the inherent trend toward centralization that we seem to see in American federalism. On the other hand, I consider the possibility that crisis may nonetheless create strong pressures for further centralization in Europe.

\footnotetext{
${ }^{20}$ I thus write with an eye to American readers as well as Europeans, with apologies where that requires telling the latter group things that they already know.

${ }^{21}$ See, e.g., David Brian Robertson, Federalism and the Making of America 112-16 (2012) (describing the origins in the New Deal in the failure of state governments to stem the tide of the Depression).

${ }^{22}$ See, e.g., Jean Pisani-Ferry, The Euro Crisis and its Aftermath (2014); Johan Van Overtveldt, The End of the Euro: The Uneasy Future of the European Union (2011).

${ }^{23}$ These are not, of course, the only comparisons to be made; the choice is dictated, instead, by the limits of the present author's plausible claims to expertise.
} 


\section{Two Europes}

There has always been a debate about whether Europe should be regarded as a federal system. On one level, the answer is obvious: The EU generally falls within standard definitions of "federalism" in constitutional and political theory. ${ }^{24}$ Political scientist Jenna Bednar, for example, classifies a government as federal if it meets structural criteria of "geopolitical division" (mutually exclusive territories are constitutionally recognized and may not be abolished by the central authority); "independence" (state and national governments have electorally or otherwise independent bases of authority); and "direct governance" (each level of government governs its citizens directly and is constitutionally sovereign in at least one policy realm). ${ }^{25}$ The EU meets these criteria. It is geopolitically divided; the European Parliament is separately elected from the Member State governments, and members of the Commission, once appointed, are insulated from the Member States' direct control; ${ }^{26}$ and both the EU and the Member States possess areas of exclusive authority under the current allocation of competences. ${ }^{27}$ And although the EU lacks a formal "constitution," its allocation of authority is nonetheless entrenched in the sense that can be changed only unanimous consent of the Member States in a new treaty. ${ }^{28}$

\footnotetext{
${ }^{24}$ See, e.g., 5 Oxford English Dictionary 795 (2d ed. 1989) (defining "federal" as "that form of government in which two or more states constitute a political unity while remaining more or less independent with regard to their internal affairs"); Michael Burgess, Comparative Federalism: Theory and Practice 2 (2006) (defining a "federation" as an "organisational form" that "accommodat[es] the constituent units of a union in the decision-making procedure of the central government by means of constitutional entrenchment"); Daniel J. Elazar, Exploring Federalism 12 (1987) ("The simplest possible definition is self-rule plus shared rule. Federalism thus defined involves some kind of contractual linkage of a presumably permanent character that (1) provides for power sharing, (2) cuts around the issue of sovereignty, and (3) supplements but does not seek to replace or diminish prior organic ties where they exist.").

${ }^{25}$ Jenna Bednar, The Robust Federation: Principles of Design 18-19 (2009). Professor Bednar's definition is similar to William Riker's. See William H. Riker, Federalism: Origin, Operation, Significance 11 (1964) (holding that a system is federal if (1) it involves "[t]wo levels of government ruling over the same land and people; (2) "each level [has] at least one area of action in which it is autonomous"; and (3) "[t]here is some guarantee of the autonomy of each government in its own sphere").

${ }^{26}$ See EC Treaty art. 213 (requiring that members of the Commission be "completely independent in the performance of their duties").

${ }^{27}$ See also David McKay, Designing Europe: Comparative Lessons from the Federal Experience 8-22 (2001) (concluding that the EU may usefully be analyzed as a federal system); R. Daniel Kelemen, Built to Last? The Durability of EU Federalism, in Sophie Meunier \& Kathleen R. McNamara, eds., Making History: European Integration and Institutional Change at Fifty, 51, 52 (2007) (noting widespread scholarly agreement on this point).

28 See, e.g., Edward L. Rubin \& Malcolm Feeley, Federalism: Some Notes on a National Neurosis, 41 UCLA L. REV. 903 (1994) (defining "federalism"-in opposition to mere "decentralization" - as a decentralized institutional arrangement that cannot be altered by the central authority, where the subunits have rights that function as 'trumps' against central power"); Andrew Moravcsik, The European Constitutional Settlement, in Meunier \& McNamara, supra note 27, at 23, 34 (stressing the formal difficulty of changes to the European treaties).
} 
To say this, though, is simply to kick the hard questions down the road. The standard definitions, after all, are quite open-ended. Carl Friedrich, for example, defined federalism as "a union of groups, united by one or more common objective, but retaining their distinctive group character for other purposes." 29 By this definition, the EU is a federal system-but so are NATO and the WTO. Hence, Michael Burgess is right to warn that "[i]f we are to understand the contemporary EU as a federal model, it is vital that we are sensitised to the peculiarities and idiosyncrasies of European integration." 30 And one must also recognize that other analytical models-for example, international organizations ${ }^{31}$ or administrative agencies ${ }^{32}$ - may also have significant analytical power in describing the relationship between the EU and its Member States.

Hence the two perspectives with which I began. I am going to call the first the "federal" perspective, but I mean federal in a stronger sense than the broad definitions just cited. The federal model takes national federal systems like the United States or Canada as appropriate comparators for the EU, and it measures the EU against those systems in terms of regulatory reach, institutional capacity, and democratic legitimacy. ${ }^{33}$ The "intergovernmental" perspective, in contrast, sees the EU as supplementary to national institutions. National governments, on this view, remain the focus of politics and administration, and the EU institutions are primary instrumental to the Members States' pursuit of their own goals. ${ }^{34}$ Proponents of this view tend to take a "liberal intergovernmentalist" approach to the dynamics of European integration. On this view, "states are the driving forces behind integration, ... supranational actors are there largely at their behest, and . . . such actors as such have little independent impact on the pace of integration." 35

Both views of the EU can fit within the capacious category of "federal" systems, and comparisons to other federal states are relevant to both. But the two perspectives suggest strongly divergent imperatives for European law.

${ }^{29}$ Carl J. Friedrich, New Tendencies in Federal Theory and Practice, Sixth World Congress of IPSA, at 1, 2 (Sept. 1964).

${ }^{30}$ Burgess, supra note 24, at 227.

${ }^{31}$ See Moravcsik, Constitutional Settlement, supra note 28, at 47.

32 See Peter L. Lindseth, Democratic Legitimacy and the Administrative Character of Supranationalism: The Example of the European Community, 99 Colum. L. Rev. 628 (1999).

${ }^{33}$ See, e.g., Larry Siedentop, Democracy in Europe x-xi (2001) (urging that integrating treaties "amount to a major step towards creating a federal state in Europe" and that "American federalism" "provides the crucial point of reference fo the the apptempt to create a European federal state today").

${ }^{34}$ See, e.g., Moravcsik, Constitutional Settlement, supra note 28 (taking this view); see also Peter L. Lindseth, Power and Legitimacy: Reconciling Europe and the Nation-State (2010); Leonard F. M. Besslink, National and Constitutional Identity Before and After Lisbon, 6 Utrecht L. Rev. 36, 38-42 (Nov. 2010) (suggesting that the intergovernmental view of the EU has come to predominate after the Maastricht and Lisbon treaties).

${ }^{35}$ Paul Craig, The Nature of the Community: Integration, Democracy, and Legitimacy, in Paul Craig \& Grainne de Burca, eds., The Evolution of EU Law 1, 10 ( $1^{\text {st }}$ ed. 1999). 


\section{A. Federal Europe}

The case for regarding the EU as closely analogous to other federal states rests on the scope of its legislative competence and the sovereign power that it exercises within that jurisdiction. By sovereignty, I mean simply the ability to exercise power with finality - that is, without being countermanded or overruled by some other actor. ${ }^{36}$ The EU's legislative competences are very broad-indeed, it seems fair to say that they are quite comparable in scope to those of the U.S. Congress. And although the EU treaties lack an American-style "Supremacy Clause," 37 the European Court of Justice (ECJ) has made clear that European law is both supreme over the law of the Member States and has direct effect within those states. In these important respects, the EU looks like a federal state.

\section{Competences}

American debates about federalism, as well as assessments of the state of our federal union, tend to focus on the competence question-that is, the allocation of regulatory authority between the nation and the states. The Supreme Court's biggest federalism case of the young twenty-first century, for example, concerned whether Congress had constitutional authority to require individuals to purchase health insurance as part of President Obama's ambitious restructuring of the American healthcare system. ${ }^{38}$ And the dramatic changes in our federal balance in the twentieth century are generally thought to be captured by the expansion of Congress's power, under contemporary interpretations of the Commerce and Necessary and Proper Clauses, to regulate virtually any aspect of the national economy. ${ }^{39}$ Although we continue to debate the outer limits of Congress's regulatory authority, all participants in those debates understand that authority to be very broad. ${ }^{40}$

The somewhat surprising fact, to American lawyers, is that European law looks fundamentally similar in the extent of powers it grants to the center. As in America, the EU started out with relatively narrow legislative jurisdiction and seemingly strict limits on expansion; according to Joseph Weiler, "the 'original' understanding [of the various European agreements] was that the principle of

\footnotetext{
${ }^{36}$ Cf. 1 William Blackstone, Commentaries on the Laws of England *49 (1765) ("[T]here is and must be in all [governments] a supreme, irresistible, absolute, uncontrolled authority, in which the jura summi imperii, or the rights of sovereignty, reside.").

${ }^{37}$ See U.S. Const. art. VI, § 2 ("This Constitution, and the Laws of the United States which shall be made in Pursuance thereof; and all Treaties made, or which shall be made, under the Authority of the United States, shall be the supreme Law of the Land . ...”).

${ }^{38}$ See National Federation of Independent Business v. Sebelius, 132 S. Ct. 2566 (2012) (holding that Congress did have this power, but only on the somewhat implausible ground that the mandate to purchase health insurance was actually a tax).

${ }^{39}$ See, e.g., Bruce Ackerman, 1 We the People: Foundations 103-04 (1991) (characterizing the shift in understanding of the scope of Congress's authority as a de facto constitutional amendment).

${ }^{40}$ See, e.g., Ernest A. Young, The Puzzling Persistence of Dual Federalism, in James E. Fleming \& Jacob T. Levy, eds., Federalism and Subsidiarity:Nomos LV 34, 54-57 (2014).
} 
enumeration would be strict and that jurisdictional enlargement . . . could not be lightly undertaken." 41 The EU's early incarnations-the Coal and Steel Community, followed by the European Community - thus were focused entirely on the establishment of a common market that provided "for free movement of factors of production in order to facilitate the optimal allocation of resources." 42 This also entailed "flanking policies' designed to prevent either the state or private parties impeding the creation of a level playing field, as exemplified by the prohibition on state aids, and the rules on competition." 43

The initial listing of competences nonetheless included both specific provisions of considerable potential breadth, such as Article 100a's provision for power over the internal market, ${ }^{44}$ and a broad provision for implied powers in Article 235. ${ }^{45}$ The European Court of Justice interpreted these provisions expansively. ${ }^{46}$ The Court gave a broad reading to Article 235, the EU's "necessary and proper" clause, ${ }^{47}$ and it made clear that it would act to promote integration even in the absence of Community legislation. ${ }^{48}$

A series of new treaties, moreover, each resulted in significant expansions of the EU's competences. The Single European Act of 1986 strengthened the EU's competences concerning the single market, made those competences easier to use by shifting from unanimous voting in the Council to qualified majority in a number of areas, and extended new competences concerning social policy, including the health and safety of workers, as well as social cohesion. ${ }^{49}$ The Maastricht and Amsterdam treaties further expanded the Union's competences, adding citizenship, consumer policy, social policy, employment, public health, foreign and security policy, and justice and home affairs. ${ }^{50}$ And as the scope of

\footnotetext{
${ }^{41}$ J.H.H. Weiler, The Transformation of Europe, 100 Yale L. J. 2403, 2433-34 (1991); see also id. at 2434 (observing that this understanding was widely shared not only by scholars but also by the Member States and Community institutions).

${ }^{42}$ Paul Craig, Competence and Member State Autonomy: Causality, Consequence and Legitimacy, in Hans Wolfgang-Micklitz \& Bruno De Witte, eds., The European Court of Justice and the Autonomy of the Member States 11, 12 (2012).

${ }^{43} I d$.

${ }^{44}$ See EC Treaty art. 100a.

${ }^{45}$ See EC Treaty art. 235 (providing power to take measures that "should prove necessary to attain ... one of the objectives of the Community" in the event that "this Treaty has not provided the necessary powers").

${ }^{46}$ Case 120/78 Rewe-Zentrale AG v Bundesmonopolverwaltung für Branntwein [1979] ECR 649 (extending the Art. 28 of the EC Treaty's prohibition on restrictions on the free movement of goods to cover nondiscriminatory rules that inhibited trade simply because they were different from the rules in the country of origin).

${ }^{47}$ See Weiler, supra note 412445-46.

${ }^{48}$ See, e.g., Case 2/74 Reyners v Belgian State [1974] ECR 631; see also Craig, Competence, supra note 42 , at 13-14.

${ }^{49}$ See Craig, Competence, supra note 42, at 16.

${ }^{50}$ See id. at 18.
} 
subjects on which Council unanimity was required for legislation continued to shrink, Community institutions were able to follow up the grants of competences in the treaties with a plethora of legislation. In particular, "[ $\mathrm{t}]$ he Commission and the European Council . . . conceptualized the single market in a broader, more holistic, manner. Consumer welfare, social policy, and environmental policy were regarded as important facets of the internal market strategy." 51

All this should seem familiar to American observers. Most national legislation rests on Congress's power to regulate interstate commerce, and although some have sought to limit that power to purely "economic" legislation, ${ }^{52}$ that position has never gotten very far. The commerce power is thus frequently used for social ends-it is the basis, for example, for federal statutes restricting marijuana use, ${ }^{53}$ "partial birth" abortion, ${ }^{54}$ and racial and gender discrimination by private actors. ${ }^{55}$ So it is unsurprising to see broad central power over the economic market mutate into broad central power to make social policy; if anything, the surprise is that Europeans thought they needed explicit textual additions to the treaties in order to make this leap. If one wanted to mandate access to abortion at EU level, for instance, any American law student would be able to make an argument that uniform rules governing access to reproductive choice is necessary to ensure the free movement of persons and access to careers throughout the single European market. ${ }^{56}$ That this would likely strike many Europeans as an implausible extension of the EU's original competences into the social field suggests, more than anything, a profound difference in legal cultureand a puzzle for comparative scholars.

The bottom line is that conferral of limited and enumerated powers has largely failed as a strategy for limiting central power in America. ${ }^{57}$ It is not all that

\footnotetext{
${ }^{51} I d$. at 20.

${ }^{52}$ See, e.g., Hammer v. Dagenhart, 247 U.S. 251 (1918) (striking down a federal law prohibiting the transport of goods produced by child labor across state lines, on the ground that the interstate movement of those goods was a pretext for achieving a social policy of prohibiting child labor). Hammer was overruled in United States v. Darby Lumber Co., 312 U.S. 100 (1941).

${ }^{53}$ See Controlled Substances Act, 21 U.S.C. $\S \S 801$ et seq.; Gonzales v. Raich, 545 U.S. 1 (2005) (upholding the Controlled Substances Act, as applied to the medicinal consumption of homegrown marijuana, under the Commerce Clause).

${ }^{54}$ See Partial-Birth Abortion Ban Act of 2003, 18 U.S.C. § 1531.

55 See, e.g., Civil Rights Act of 1964, Title II, 42 U.S.C. $\S 2000$ a (forbidding discrimination in public accomodations); Katzenbach v. McClung (upholding Title II as a valid exercise of the Commerce Power).

${ }^{56}$ Cf. Planned Parenthood of Southeastern Pennsylvania v. Casey, 505 U.S. 833, 856 (1992) (joint opinion of O'Connor, Kennedy, \& Souter, JJ) ("[T] he ability of women to participate equally in the economic and social life of the Nation has been facilitated by their ability to control their reproductive lives.").

${ }^{57}$ See, e.g., Young, Making Federalism Doctrine, supra note 88, at 1786; Edward S. Corwin, The Passing of Dual Federalism, 36 Va. L. Rev. 1 (1950).
} 
surprising to find that a similar strategy has not worked well in Europe, ${ }^{58}$ and that the Community has been able to exercise a broad range of powers comparable to a relatively centralized federal state.

\section{Sovereignty}

Americans tend, on the other hand, to take the sovereignty questions for granted. The key issues were settled long ago. The Constitution explicitly declared the supremacy of national law, and the Supreme Court early on held that the States may not exercise their own powers in ways that interfere with federal legislation or federal institutions. ${ }^{59}$ Talk of state sovereignty thus generally refers to the States' legislative authority in those few areas falling outside the scope of Congress's enumerated powers or the integrity of state governmental institutions vis-à-vis federal interference. ${ }^{60}$ But no one questions the supremacy or direct effect of national law. ${ }^{61}$

Europe's treaties lacked an explicit Supremacy Clause, and the ECJ's role has been correspondingly important in establishing the sovereignty of European law. Beginning in the 1960s, the Court announced that EU law had direct effect within national legal systems ${ }^{62}$ and was, in fact, supreme over national law. ${ }^{63}$ Moreover, the Court determined that when EU competences overlapped with areas of reserved Member State authority, EU law would nonetheless prevail. ${ }^{64}$ To an

\footnotetext{
${ }^{58}$ See, e.g., Robert Schütze, From Dual to Cooperative Federalism: The Changing Structure of European Law 184-88 (2009).

${ }^{59}$ See, e.g., McCulloch v. Maryland, 17 U.S. (4 Wheat.) 316 (1819) (holding that Maryland could not impose a tax on the Bank of the United States); see also Arizona v. United States, $132 \mathrm{~S}$. Ct. 2492 (2012) (holding that Arizona could not adopt laws interfering with national immigration policy).

60 See, e.g., Printz v. United States, 521 U.S. 898 (1997) (holding that Congress may not "commandeer" state officials by forcing them to enforce federal law); Seminole Tribe v. Florida, 517 U.S. 44 (1996) (holding that Congress may not subject the states to private suits for money damages).

${ }^{61}$ Although the federal courts have developed an extensive jurisprudence of preemption, the courts in such cases simply attempt to divine how far Congress has intended to displace state law by enacting a federal statute; they do not question Congress's power to do so. See, e.g., Ernest A. Young, "The Ordinary Diet of the Law": The Presumption Against Preemption in the Roberts Court, 2011 Sup. Ct. Rev. 253 (surveying preemption jurisprudence).

${ }^{62}$ Case 26/62, Algemene Transport-en Expedetie Onderneming van Gend en Loos NV v. Nederlands Administratie der Belastingen, 1963 E.C.R. 1, [1963] 2 C.M.L.R. 105 (1963).

${ }^{63}$ See, e.g., Case 6/64, Costa v. ENEL, 1964 E.C.R. 585, 594, [1964] C.M.L.R. 425, 455 (1964); see also Case 11/70, Internationale Handelsgesellschaft $\mathrm{mbH}$ v. Einfuhr-und Vorratsstelle ffir Getreide und Futtermittel, 1970 E.C.R. 1125,1134 para. 3, [1972] C.M.L.R. 255, 283 para. 3 (1972) ("[T]he validity of a Community measure or its effect within a Member State cannot be affected by allegations that it runs counter to either fundamental rights as formulated by the constitution of that State or the principles of a national constitutional structure.").

${ }^{64}$ Case 9/74, Casagrande v. Landeshauptstadt Munchen, 1974 E.C.R. 773, [1974] 2 C.M.L.R. 423 (1974).
} 
American observer, it is as if Chief Justice John Marshall had decided McCulloch v. Maryland ${ }^{65}$ without the benefit of any explicit textual support.

Certain aspects of the sovereignty of EU law remain contested in principle, if rarely contravened in practice. In a number of high profile cases, national constitutional courts-particularly the German Federal Constitutional Court (GFCC)-have insisted on two important qualifications to the supremacy of European law. The first is that although the GFCC generally concedes the supremacy of EU law, it has long claimed kompetanz kompetanz- that is, the right to a final say concerning whether the EU institutions have transgressed the limitations of their competences as provided in the treaties. ${ }^{66}$ The constitutional courts of several other Member States have taken a similar position. ${ }^{67}$ The U.S. Supreme Court confronted this issue early on in Martin v. Hunter's Lessee, ${ }^{68}$ which held that the U.S. Supreme Court had constitutional authority to review decisions of the state supreme courts on matters of federal law. ${ }^{69}$ In Europe, by contrast, the old Virginian opponents of national judicial supremacy appear to be winning. ${ }^{70}$ On the other hand, the GFCC has yet actually to find any EU actions invalid, preferring to uphold EU actions while insisting on its right to decide. ${ }^{71}$

The second qualification is that the GFCC, again joined by several other national courts, insists that European law cannot trump certain aspects of domestic

\footnotetext{
${ }^{65} 17$ U.S. (4 Wheat.) 316 (1819) (broadly construing Congress's implied powers under Article I's "necessary and proper" clause and holding that state law could not interfere with the valid exercise of federal powers).

${ }^{66}$ See Brunner v. European Union Treaty, [1994] 1 C.M.L.R. 57 (1993); see also Julio Baquero Cruz, The Legacy of the Maastricht-Urteil and the Pluralist Movement, 14 Eur. L. J. 389, 392-93 (2008); Erin Delaney, Managing in a Federal System without an 'Ultimate Arbiter': KompetenzKompetenz in the EU and the Ante-bellum United States, 15 Reg. \& Fed. Stud. 225 (2005).
}

${ }^{67}$ See, e.g., the decision of the Danish Supreme Court in Carlson and Others v. Rasmussen, Case No. I-361/1997 (1998) (insisting that "national courts cannot be deprived of their right to examine the question of whether a particular EC legal act exceeds the limits for a transfer of sovereignty brought about by the Act of Accession"); see also Cruz, supra note 66, at 398-402 (noting similar decisions by the constitutional courts of Poland, Cyprus, the Czech Republic, France, and Spain); Delaney, supra note 66, at 232.

${ }^{68} 14$ U.S. (1 Wheat.) 304 (1816).

${ }^{69}$ The issue was not politically settled, however, until the late nineteenth century. See Richard H. Fallon, Jr., John F. Manning, Daniel J. Meltzer, \& David L. Shapiro, Hart and Wechsler's The Federal Courts and the Federal System 474-76 (7th ed. 2015).

${ }^{70}$ See, e.g., G. Edward White, The Marshall Court and Cultural Change, 1815-1835, at 496 (1991) (describing the Virginia view that state courts are bound by federal law, but not by the U.S. Supreme Court's interpretations of that law).

${ }^{71}$ See, e.g., Delaney, supra note 66, at 233 (describing conflict avoidance by both the GFCC and the ECJ); see also Christian Joerges, Is There a Guardian of Constitutionalism in the European Union?, in Champeau, Closa, Innerarity, \& Maduro, supra note 4, at 75, 80 (arguing that the GFCC's cases concerning the Euro crisis have "consolidat[ed]" the GFCC's "ambiguous reputation" as "a dog 'that barks but does not bite"”). 
constitutional law. ${ }^{72}$ One may find an EU law hook for this position in the Maastricht and Lisbon treaties' commitment to respect the "national identity" of the Member States, which may be read to include their constitutional identity. ${ }^{73}$ In the United States, it is well established not only that federal law trumps state law, but that this relationship is indifferent as to the form that state law takes. Hence, even a federal regulation issued by a federal administrative agency can trump a state constitutional provision, so long as the regulation was validly issued. ${ }^{74}$ This makes some sense in light of the States' tendency to enshrine mundane (and often seemingly random) provisions in the state constitution rather than statute law; for instance, the New York Constitution regulates the width of ski trails. ${ }^{75}$

The German Basic Law, in contrast, explicitly sets certain provisions apart as unamendable, including the provisions on democratic authority upon which the GFCC has relied in its challenges to European law. ${ }^{76}$ More generally, the European human rights tradition has generally been more willing than the American to ground those rights in universal and fundamental values-a tendency that not only sets certain constitutional principles apart from ordinary law but also suggests they should be binding on the EU as well as particular Member States ${ }^{77}$ Hence, several European national courts have limited their exceptions to EU supremacy to "fundamental" principles in national constitutions. ${ }^{78}$

${ }^{72}$ See, e.g., Gareth Davies, Constitutional Disagreement in Europe and the Search for Pluralism, in J. Komarek \& M. Avbelj, eds., Constitutional Pluralism in the European Union and Beyond 269, 272-74 (2012); Leonard F. M. Besselink, National and Constitutional Identity Before and After Lisbon, 6 Utrecht L. Rev. 36, 46 (2010) ("[T]he highest and constitutional courts in the large majority of Member States do not recognize [EU law's] precedence over the national constitution."); Cruz, supra note 66, at 398-402.

${ }^{73}$ See Besselink, supra note 72, at 47-48.

${ }^{74}$ See, e.g., Fidelity Fed. Savings \& Loan Assn. v. De la Cuesta, 458 U.S. 151, 153 (1982) ("Federal regulations have no less pre-emptive effect than federal statutes."); Van Patten v. Jensen, 773 P.2d 62, 64 (Wa. 1989) (holding a state constitutional provision preempted by a federal regulation). The conclusion that federal regulations are supreme federal law is, to put it mildly, not obvious from the text of the Supremacy Clause, which speaks in terms of federal statutes, treaties, and cosnstitutional provisions. See, e.g., Bradford R. Clark, The Supremacy Clause as a Constraint on Federal Power, 71 Geo. Wash. L. Rev. 91 (2003). But the doctrine is well settled.

${ }^{75}$ See N.Y. Const. art. XIV, § 1. But see Emily Zackin, Looking for Rights in All the Wrong Places: Why State Constitutions Contain America's Positive Rights 28-32 (2013) (explaining that NY's infamous ski trail provision was part of a constitutional commitment to the conservation of public lands and that state constitutions in fact contain a range of fundamental commitments).

${ }^{76}$ Art. 79, para. 3 GG. That quality forecloses any reading of German accession to the EU's treaties as overriding these basic commitments in national law.

77 See, e.g., Jed Rubenfeld, Unilateralism and Constitutionalism, 79 N.Y.U. L. Rev. 1971, 1975 (2004).

78 See, e.g., CC Décision no 2006-540 DC (27 July 2006) (holding that an EU law may be declared to be in violation of the French constitution only if it infringes a rule or principle that is inherent in French "constitutional identity"); Italian Fragd Case, Corte Costitutzionale, Decision No. 232, April 21, 1989, 72 RDI (1989) 103 (limiting invalidity of EU law to conflicts with "fundamental" principles of Italian constitution); see generally Besselink, supra note 72, at 46- 
Not altogether surprisingly, the ECJ has taken the view that national constitutions are subordinate to EU law. ${ }^{79}$ It is not hard to see why. American lawyers, who may be more conditioned to opportunistic invocations of constitutional principle, can readily imagine a Member State using its national constitution as a basis for opting out of some aspect of European law that doesn't suit its interests. So far this does not seem to have happened. Although some national court decisions have struck down particular provisions of EU law for incompatibility with national constitutions, ${ }^{80}$ these isolated cases do not appear to have sparked a fundamental conflict between courts. Indeed, the ECJ seems to have avoided pressing the issue by moderating its position in some recent cases. ${ }^{81}$ Still, we should not rule out the possibility that one or both sides may in future choose to play what Mark Tushnet calls "constitutional hardball." 82 The erosion of the national veto in the Council, for example, may encourage States to press other means for opting out of policies they oppose. If that occurs, then the ECJ may feel compelled to take a firm stand on the other side.

Rumblings about the limits of integration from the national courts may yet break out into a fundamental disagreement about the nature and scope of the European legal order-particularly in the case of the EU's response to the Euro

47. The use of such a distinction underscores a fundamental difference in American and European legal cultures. Conservative and liberal lawyers in America would be unlikely to agree on which constitutional rights were "fundamental" or part of an American constitutional "identity"-abortion? the right to bear arms? - and they certainly would not trust a court to decide that issue for them. The ECJ has recently suggested that it may have the authority to decide which aspects of national constitutions are crucial in this way - a step that may raise the same sort of controversies even among less contentious Europeans. See Case C 213/07, Michaniki AE v Ethniko Simboulio Radiotilearasis [2008] ECJ 16; see also Besselink, supra note 72, at 48 (discussing Michaniki and recognizing that "it is a risky enterprise to project a EU ranking of values onto national constitutional law").

79 See Case 11/70 Internationale Handelsgesellschaft mbH v Einfuhr- und Vorratsstelle für Getreide und Futtermittel [1970] ECR 1125 ("[T] within a Member State cannot be affected by allegations that it runs counter to either fundamental rights as formulated by the Constitution of that state or the principles of a national constitutional structure.").

${ }^{80}$ See, e.g., Oreste Pollicino, European Arrest Warrant and Constitutional Principles of the Member States, 9 German L. J. 1313 (2008) (discussing decisions by the GFCC as well as the constitutional courts of Poland and Cyprus invalidating national laws implementing an EU directive creating a European arrest warrant).

81 See, e.g., Case C-36/02, Omega Spielhallen und Automatenaufstellungs-GmbH $v$ Overbürgermeisterin der Bundesstadt Bonn [2004] ECR 1-9609 (holding that a German law challenged under European law as a impediment to the free movement of goods was valid because the national courts had determined the law to be necessary to protection of human dignity under the German Basic Law); see also Besselink, supra note 72, at 45-46 (suggesting that the ECJ now takes a more nuanced approach and is "far beyond" its earlier position).

82 See Mark Tushnet, Constitutional Hardball, 37 J. Marshall L. Rev. 523 (2004). Wikipedia's definition captures Tushnet's use of the term well: "Hardball . . generally refers to baseball (as opposed to its variant softball), especially when played very competitively. Metaphorically, it refers to uncompromising and ruthless methods or dealings, especially in politics." Wikipedia, http://en.wikipedia.org/wiki/Hardball, visited Feb. 17, 2014. 
crisis. $^{83}$ That conflict has not yet materialized however. In the vast range of cases that do not implicate fundamental rights or democratic principles, the supremacy of EU law seems hardly less well-established than in the United States.

\section{Subsidiarity}

The treaties do contain one legal check on the exercise of central competence that has no immediate analog in America-the principle of "subsidiarity," added to what is now Article V of the EC Treaty by the Treaty of Maastricht. That principle provides that

In areas which do not fall within its exclusive competence, the Community shall take action, in accordance with the principle of subsidiarity, only if and insofar as the objectives of the proposed action cannot be sufficiently achieved by the Member States and can therefore, by reason of the scale or effects of the proposed action, be better achieved by the Community. ${ }^{84}$

As Ed Swaine has observed, "[s]ubsidiarity is a critical reaction not only to the gradual shift in legislative authority from the Member States-dominated Council to more autonomous Community institutions, but also to the Court of Justice's expansive interpretation of Community powers against the apparent interest of Member States." 85 Subsidiarity operates in conjunction with the principle of conferral-analogous to the American notion of enumerated powers-and proportionality, which holds that "[a]ny action by the Community shall not go beyond what is necessary to achieve the objectives of this Treaty." 86

Subsidiarity's advocates originally thought that the principle would be judicially enforced, but the ECJ has largely disappointed those hoping for a significant judicial check on EU action. ${ }^{87}$ This is not surprising: In America, the Supreme Court has exerted relatively little constraint on centralization, and comparative research suggests that constitutional courts are generally better at

${ }^{83}$ See Part II.B, infra.

${ }^{84}$ EC Treaty art. 5.

${ }^{85}$ Edward T. Swaine, Subsidiarity and Self-Interest: Federalism at the European Court of Justice, 41 Harv. Int'l L. J. 1, 5 (2000); see also Young, European Union, supra note 18, at 1677-82 (discussing subsidiarity).

${ }^{86}$ EC Treaty art. 5.

${ }^{87}$ See, e.g., Paul Craig, Institutions, Power, and Institutional Balance, in Paul Craig \& Grainne de Burca, eds., The Evolution of EU Law 41 (2d ed. 2011) (stating that subsidiarity has not providd an "effective limit"); Christoph Ritzer, Marc Ruttloff, \& Karin Linhart, How to Sharpen a Dull Sword-The Principle of Subsidiarity and its Control, 7 German L. J. 733, 760 (2006) ("In the jurisprudence of the European Courts the principle of subsidiarity has so far only been of little value as a standard of scrutiny."); Jan M. Smits, Who Does What? On Cameron, Rutte and the Optimal Distribution of Competences Among the European Union and the Member States, Maastricht European Private Law Institute Working Paper No. 2013/16 (December 7, 2013), at 7, available at SSRN: http://ssrn.com/abstract=2364730 ("[I]n the twenty years since this principle was codified ... it did not develop into a useful criterion for the vertical distribution of competences."). 
reining in subnational units than at preventing central overreach. ${ }^{88}$ Moreover, subsidiarity calls for a predictive judgment about the relative effectiveness of action at various levels of government that courts are ill-equipped to make, and the principle itself provides no guidance as to what sort of tradeoffs between the policy under consideration and the values of localism should be made. ${ }^{89}$ It is hard to sustain the legitimacy of a judicial check on legislative decisions when the factors that the courts must consider are substantively identical to those already passed upon by the legislature. ${ }^{90}$ If anything, the failure of subsidiarity as a principle of judicial review in Europe ought to give pause to American scholars who have pressed courts to use a similar principle to construe the reach of Congress's legislative powers. ${ }^{91}$

More recently, however, subsidiarity advocates have emphasized its utility as a principle to guide - and to be enforced by-political institutions. A protocol in the Treaty of Amsterdam required the EU's central institutions to respect the principle of subsidiarity in the exercise of their powers and required those institutions, particularly the Commission, to jump through a number of procedural hoops before exercisting power at EU level. ${ }^{92}$ American law contains similar features, but they have not done much. Every recent president, for example, has issued an executive order on federalism requiring federal agencies to consider the impact of proposed actions and regulations on state law and autonomy, ${ }^{93}$ but these

${ }^{88}$ See, e.g., Ernest A. Young, Making Federalism Doctrine: Fidelity, Institutional Competence, and Compensating Adjustments, 46 Wm. \& Mary L. Rev. 1733, 1751-53 (2005) (noting the predominantly centralizing role of the Supreme Court in American history); Jenna Bednar, William N. Eskridge, Jr., \& John Ferejohn, A Political Theory of Federalism, in John Ferejohn, Jack N. Rakove, \& Jonathan Riley, eds., Constitutional Culture and Democratic Rule 223, 233 (2001) (concluding that institutional factors make constitutional courts situated at the center more likely to check subnational divergence from national norms than overreach by the central authority).

89 See Young, European Union, supra note 85, at 1678-80; George A. Bermann, Taking Subsidiarity Seriously: Federalism in the European Community and the United States, 94 Colum. L. Rev. 331, 391 (1994) ("The same characteristics that make the inquiry difficult for the political branches to conduct - namely, uncertainty about how much localism really matters on a given issue, the heavy reliance on prediction and the probabilities of competing scenarios, the possibility of discretionary tradeoffs between subsidiarity and proportionality, and the sheer exercise of political judgment entailed - make the inquiry even more problematic for the Court.").

90 See, e.g., Lawrence Lessig, Translating Federalism: United States v. Lopez, 1995 Sup. Ct. Rev. $125,174-75$.

91 See, e.g., Robert D. Cooter \& Neil Siegel, Collective Action Federalism: A General Theory of Article I, Section 8, 63 Stan. L. Rev. 115 (2010); Stephen Gardbaum, Rethinking Constitutional Federalism, 74 TEX. L. REV. 795, 826-27 (1996); Donald H. Regan, How to Think About the Federal Commerce Power and Incidentally Rewrite United States v. Lopez, 94 Mich. L. Rev. 554, 557 (1995).

92 See TEU Protocol No. 2 (1997).

93 See, e.g., Preemption: Memorandum for the Heads of Executive Departments and Agencies, 74 Fed. Reg. 24,693, 24,693-94 (May 20, 2009) (Obama); Exec. Order No. 13,132, 64 Fed. Reg. 43,255 (Aug. 4, 1999) (Clinton). 
analyses have generally been pro forma when issued; more frequently, agencies have simply ignored the requirement altogether. ${ }^{94}$

The Lisbon Treaty went further by incorporating the subsidiarity elements of the failed Constitutional Treaty, which retained "[s]ubsidiarity [as] the centrepiece of competence control" "95 but continued the shift from judicial to political implementation. Lisbon established an elaborate procedure whereby national parliaments would have a voice in determining whether proposed EU legislation satisfies the subsidiarity principle. ${ }^{96}$ It remains to be seen whether this new institutional framework for implementing subsidiarity will make a practical difference. However, these frameworks will not eliminate Professor Davies' more principled objection to subsidiarity as a constraint on EU action, which is that it necessarily asks only whether an EU policy can be more effectively vindicated by Member State action-not whether the Member States' own policies and preferences should have independent weight. ${ }^{97}$

\section{Constitutionalism and the Democratic Deficit}

In any event, neither subsidiarity nor the strong political checks built into the EU's structure have prevented the accumulation of a vast range of competences at the center. Disagreement remains as to whether the treaty's broad allocations of competence or their subsequent interpretation by the ECJ is to blame, ${ }^{98}$ but there is little doubt that the European Union's authority is now very broad indeed. It seems fair to say, in fact, that outside the realm of foreign and defence policy (an important exception), the competences of the EU institutions are no less impressive than those of the U.S. Congress. Scholars and politicians debate the proportion of the law in any given Member State that emanates from Brussels, but even conservative estimates see a very significant EU imprint on national legal systems. 99 As Gareth Davies has written, "[t]he scope of Community activity is now so broad that few if any areas of national policy are immune from its effects." ${ }^{100}$ And EU law is sovereign in the same sense as federal

\footnotetext{
${ }^{94}$ See, e.g., Nina A. Mendelson, Chevron and Preemption, 102 Mich. L. Rev. 737, 782-86 (2004). On the broader notion of enforcing limits on national power through the administrative process, compare Brian Galle \& Mark Seidenfeld, Administrative Law's Federalism: Preemption, Delegation, and Agencies at the Edge of Federal Power, 57 Duke L. J. 1933 (2008) (praising the idea), with Stuart Minor Benjamin \& Ernest A. Young, Tennis with the Net Down: Administrative Federalism without Congress, 57 Duke L. J. 2111 (2009) (throwing cold water).

95 Gareth Davies, Subsidiarity: The Wrong Idea, in the Wrong Place, at the Wrong Time, 43 Common Mkt. L. Rev. 63, 67 (2006).

96 See Philipp Kiiver, The Treaty of Lisbon, the National Parliaments and the Principle of Subsidiarity, 15 Maastricht J. Eur. \& Comp. L. 77 (2008).

${ }^{97}$ Davies, Subsidiarity, supra note 95, at 67-68.

98 See Paul Craig, Competence: Clarity, Containment and Consideration, 29 Euro. L. Rev. 323, 324-25 (2004) (taking the former view).

99 See, e.g., See Vaughne Miller, How much legislation comes from Europe? House of Commons Library Research Ppaer 10/62, Oct. 13, 2010, at 12.

${ }^{100}$ Davies, Subsidiarity, supra note 95, at 63.
} 
law in the United States: EU law has direct effect within the Member States, and, subject to certain narrow reservations voiced by national courts, it is supreme over those states' own laws.

This view of the EU as a federal state has implications for how the EU should move forward. It lends plausibility, for one thing, to the recent movement to replace the EU's amalgam of treaties with an honest-to-goodness constitution. Treaties, after all, are for alliances and supranational institutions - not integrated federal states. That the Member States considered it possible to just drop the "constitutional" treaty after its rejection by France and the Netherlands in 2005while adopting much of its substance in the Lisbon Treaty-suggests limits on a federalist perspective. But one suspects that aspirations for a formal constitution will not remain dead forever.

The constitutionalist movement, moreover, was not just about form but also about substance. The expansion of EU competence has been accompanied by a significant politicization of the EU's functions. As Hartmut Kaelble has observed, "important new fields became part of a broadly based and widely debated process of Europeanization including labor markets, consumer and environmental protection, human rights, foreign workers, student exchange programs, university exams, drivers' licenses, identity cards, and border controls." 101 The result was that "[a]fter the mid-1980s, debates on Europe became more contentious, with increasingly clear contrasts between supporters and opponents of the European project." 102 One consequence is that debates about constitutional structure are increasingly driven by preferences about outcomes. ${ }^{103}$ That situation is, of course, familiar to American constitutional lawyers.

In the early days of the European Community, the Community's powers were grounded in peace and prosperity. The general project of integration rested on a moral commitment to preventing war in Europe and particular policies could count on deference to technocratic expertise. ${ }^{104}$ As Professor Kaelble puts it, "there had existed a diffuse and largely uncontroversial general support for complicated expert decisions, for example on the creation of a common market, a common agricultural policy, and various European funds."105 As memories of war faded and the post-war recovery boom abated, peace was taken for granted and prosperity was called into question. Moreover, the expansion of the EU's legislative competence brought European law into areas where the public is less willing to defer to technocratic expertise. Europe has thus seen not only calls to recalibrate its goals-typically, by emphasizing social protection alongside

\footnotetext{
${ }^{101}$ Hartmut Kaelble, Identification with Europe and Politicization of the EU Since the 1980s, in Checkel \& Katzenstein, supra note 14, at 193, 194.

${ }^{102}$ Id. at 194.

103 See, e.g., The Paradox of Euroscepticism, The Economist, Feb. 1, 2013, available at http://www.economist.com/blogs/blighty/2013/02/british-politics.

${ }^{104}$ See Craig, Competence, supra note 42, at [18-19].

${ }^{105}$ Kaelble, supra note 101, at 194.
} 
economic liberalization-but also to democratize its processes. Paul Craig describes this movement as a shift from "output legitimacy" to "input legitimacy." 106 Delivering peace and prosperity is no longer enough; citizens expect a right to participate in a democratic process of governance.

If the EU is held to the "input" standards of a "national" democracy, then it looks highly unsatisfactory in at least two respects. First, the only arm of EU government that is directly elected by the People-the European Parliamentcontinues to have meager authority compared to national parliaments of the Member States. ${ }^{107}$ More fundamentally, many observers have questioned whether democratic politics can even exist at the European level, because Europe lacks pan-European political parties and most citizens do not self-identify as "European" rather than French or German or Latvian. ${ }^{108}$

Importantly, this perspective sees the current arrangements as inherently unstable and in need of reform. It is unacceptable, on this view, for Brussels to wield the scope of power that it does without becoming more democratic and developing a deeper well of popular identification. These criticisms have thus yielded several imperatives for reform-some of which is already underway. The last several treaties have incrementally expanded the European Parliament's role in various ways. ${ }^{109}$ Brussels has taken steps to improve the oft-criticized transparency of EU governmental processes. ${ }^{110}$ And the EU has undertaken a variety of initiatives - creating and promoting a flag, for instance, and a pantheon of pan-European heroes ${ }^{111}$ - to bolster a sense of "European" identity among its citizens. All of these measures are designed to help bring the EU's democratic legitimacy and popular mandate in line with the scope and effect of its legislative power.

It may be that, as Professor Moravcsik argues, "[t]he issues publics care about most remain overwhelmingly national," and that "[t]he issues the EU deals with most intensely - trade, industrial regulation, technical standardization, soft power projection, foreign aid, agricultural policy, infrastructural, and general foreign policy-are not salient issues for the mass public."112 This particular

\footnotetext{
${ }^{106}$ Craig, Competence, supra note 42, at 24.

${ }^{107}$ See, e.g., Habermas, Democracy, supra note 1.

${ }^{108}$ See, e.g., Francis Fukuyama, The Challenges for European Identity, Global, Jan. 11, 2012, available at http://theglobaljournal.net/article/view/469/; see also Michael Marder, Carl Schmitt and the Deconstitution of Europe, in Champeau, Closa, Innerarity, \& Maduro, supra note 4, at 95, 98-99 (arguing that citizens of the EU do not "share a common political existence").

${ }^{109}$ See, e.g., Craig, Nature of the Community, supra note 35, at 38.

${ }^{110}$ See, e.g., Moravcsik, Constitutional Settlement, supra note 28, at 43 ("Cross-national research reveals that EU regulatory procedures are as transparent and open to public input as the best practices of national governments.").

${ }^{111}$ See Luuk van Middelaar, The Passage to Europe: How a Continent Became a Union 233-38 (2013).

${ }^{112}$ Moravcsik, Constitutional Settlement, supra note 28, at 41.
} 
assessment from 2007, which discounted the salience of the EU's role in monetary policy as "obscure" in circumstances "short of a crisis," 113 has likely been overtaken by events. But there is also little doubt that the overall salience and politicization of EU activity has increased as the EU's competences have expanded, and many have responded by urging reforms that will significantly enhance the EU's resemblance to a federal state. ${ }^{114}$

\section{B. Intergovernmental Europe}

A second perspective finds all this talk of "democratic deficit" and "European identity" misguided. On this view, the EU is not a nascent federal system but rather an extremely successful international organization. As Andrew Moravcsik has written, "[t]he EU remains, despite a few federal elements, essentially a confederation of nation-states: the most ambitious and successful among international organizations, rather than a federation aiming to replicate and supplant European nation-states."115 It remains true, for example, that "the Union is treaty-based and is characterized by voluntary membership and unanimity requirements for treaty amendments and other key decisions."

This intergovernmental perspective gives relatively short shrift to the scope of the EU's regulatory jurisdiction ${ }^{117}$ and the sovereign effect of EU legislation and instead focuses on the EU's limited institutional capacity, the primary role of national governments in implementing EU law, and the tendency of EU citizens to identify primarily with their Member States. These factors severely constrain the EU's ability to act in the manner of a centralized government; hence, on this view, it is better to think of the EU as a new form of supranational governance. ${ }^{118}$

\section{Governmental Capacity}

The most outspoken advocate for this intergovernmental perspective, Professor Moravcsik, emphasizes that "the EU does not (with a few exceptions)

\footnotetext{
${ }^{113} I d$.

${ }^{114}$ See generally F. Fabbrini, Economic Governance, supra note 10.

${ }^{115}$ Moravcsik, Constitutional Settlement, supra note 28, at 24.

116 Stephen C. Sieberson, Inching Toward Supranationalism? Qualified Majority Voting and Unanimity under the Treaty of Lisbon, 50 Va. J. Int'1 L. 919, 930 (2010).

117 Professor Moravcsik does say that "[m]ost of the important substantive areas of modern governance remain firmly in the hands of national governments, to be extended only by unanimous vote of the Member States." Moravcsik, Constitutional Settlement, supra note 28, at 34. To the extent that is true, however, is seems more a matter of legislative grace rather than constitutional allocation. If the conferred powers of the EU were read as broadly as, say, analogous textual enumerations in the U.S. constitution, then it is hard to think of many policy areas that would remain off limits to Brussels.

118 See Moravcsik, Without Illusions, supra note 3, at 8; see also Deirdre M. Curtin \& Ige F. Dekker, The EU as a 'Layered' International Organization: Institutional Unity in Disguise, in Craig \& De Burca, supra note 35 , at 83.
} 
enjoy the power to coerce, administer, or tax."119 It may be useful to think of three distinct dimensions of the EU's governmental capacity: its capacity to make decisions that are autonomous vis-à-vis the Member States; its institutional and financial resources; and its ability to raise those resources and regulate via taxation. In each of these areas, the EU institutions seem far more constrained than a federal state like the U.S.

First, decision-making. American federalism scholars have long known that the procedures by which a central government makes law provide a key measure of its power; after all, the more easily the center can make law, the more likely it is to make inroads on the periphery's autonomy. ${ }^{120}$ Professor Moravcsik argues that it is extremely difficult for the EU institutions to make law: "Formally, [the European lawmaking process] makes everyday legislation in the EU as difficult to enact as a constitutional amendment in the USA."121 If that were true, however, then one would expect to see a lot less EU legislation than Brussels manages, in fact, to produce. In the two-year period of 2008 and 2009, the EU Council and Commission enacted a total of 253 directives and 2157 regulations. ${ }^{122}$ By way of comparison, the $110^{\text {th }}$ Congress enacted 460 laws in the same period. ${ }^{123}$ There are, of course, all sorts of problems in comparing raw numbers of laws enacted in the two systems. But while the apples-to-oranges difficulty might slow down a claim that the EU legislates far more easily than Congress, it seems hard to deny that Brussels has a capacity to enact legislation comparable to that of a federal state.

Likewise, Professor Moravcsik suggests that "constitutional" change-that is, change to the governing treaties-is more difficult in the EU than in "any modern democracy except perhaps that of Switzerland." 124 And yet we have seen significant and extensive revisions to the treaties in 1965 (Brussels), 1986 (Single

\footnotetext{
${ }^{119}$ Moravcsik, Constitutional Settlement, supra note 28, at 34.

${ }^{120}$ See, e.g., Bradford R. Clark, Separation of Powers as a Safeguard of Federalism, 79 Tex. L. Rev. 1321 (2001); Ernest A. Young, Two Cheers for Process Federalism, 46 Vill. L. Rev. 1349, 1361-64 (2001).

${ }^{121}$ Moravcsik, Constitutional Settlement, supra note 28, at 34.

122 See Miller, supra note 99, at 12 (collecting statistics on lawmaking from the EUR-lex database).

${ }^{123}$ See U.S. House of Representatives, Office of the Clerk, Final Resume of Congressional Activity, First Session of the One Hundred Tenth Congress, at http://library.clerk.house.gov/reference-files/RCA 110 1.pdf (visited Feb. 8, 2014); Office of the Clerk, Final Resume of Congressional Activity, Second Session of the One Hundred Tenth Congress, at http://library.clerk.house.gov/reference-files/RCA 110_2.pdf (visited Feb. 8, 2014). Congress's more recent output has been considerably less. See Amanda Terkel, 112th Congress Set to Become Most Unproductive Since 1940s, Huffington Post, Dec. 28, 2012, available at http://www.huffingtonpost.com/2012/12/28/congress-unproductive n 2371387.html (reporting 383 bills for the 111th Congress (2009-10) and only 239 bills for the 112th (2011-12)).

${ }^{124}$ Moravcsik, Constitutional Settlement, supra note 28, at 34. After all, "unanimity is required, often with ratification by referendum in at least some of the member states, and by at least parliamentary vote in all." $I d$.
} 
European Act), 1992 (Maastricht), 1997 (Amsterdam), 2001 (Nice), and 2007 (Lisbon). In the same period, there have been only five amendments to the U.S. Constitution, and none of them dealt with matters of equivalent significance to the EU's treaty revisions. ${ }^{125}$ If it's so hard to change the EU legal order, why does it happen so often?

The question is only partly rhetorical, because Professor Moravcsik is plainly right that the institutional gauntlet confronting both legislation and treaty revision in Europe is quite daunting. If the American producers of "Schoolhouse Rock" were to create an "I'm Just a Directive" cartoon to explain the process of EU legislation, ${ }^{126}$ the protagonist legislative proposal would face a longer and more intimidating journey in Brussels than in Washington, D.C. As Moravcsik explains, "[f]or legislation to pass, the Commission must propose (by majority or consensus), the Council of Ministers must decide (by supermajority vote), [and] European parliamentarians must assent (by absolute majority of members)." ${ }^{127}$ The EU's ability to produce so much law and to agree on such frequent and farreaching "constitutional" change is thus a significant puzzle for comparative scholars.

One thing seems clear, however. The EU legislative process incorporates a great deal more political constraint on central lawmaking that adversely affects the Member States than does its American analog. First and foremost, the EU Council directly represents the individual Member States. American scholars debate whether members of the U.S. Congress, elected by their States (or from districts within their States) but not accountable to the governments of their States, are likely to act on behalf of their States' interests once in Washington, D.C. ${ }^{128}$ The

${ }^{125}$ See U.S. Const. amend. XXIII (1961) (granting the District of Columbia representation in the Electoral College); U.S. Const. amend. XXIV (1964) (banning poll taxes); U.S Const. amend. XXV (1967) (establishing rules for Presidential disability and succession); U.S. Const. amend. XXVI (1971) (extending the vote to persons aged 18-20); U.S. Const. amend. XXVII (1992) (prohibiting laws altering congressional salaries from taking effect until after an intervening election). Overall, the American Constitution has been amended only twenty-seven times. Ten of those occurred as part of the Bill of Rights, ratified two years after the original constitution and essentially as part of the same "constitutional moment." Three more occurred as part of Reconstruction following the Civil War. Most American constitutional scholars agree, as a predictive matter, that the U.S. Constitution simply cannot be amended in any way that arouses even minimal political controversy. See, e.g., Sanford Levinson, Our Undemocratic Constitution: Where the Constitution Goes Wrong (And What We the People Can Do to Correct It) 159-66 (2008). Hence, most of the modern amendments were either overwhelmingly popular, like allowing eighteen-year-olds to vote, amend. XXVI, or involved primarily housekeeping measures, such as the rules for succession in the event of a presidential disability, amend. XXV.

${ }^{126}$ The best account of the U.S. lawmaking process remains the famous "I'm Just a Bill" cartoon televised on Saturday mornings in the 1970s and 1980s. See Schoolhouse Rock, I'm Just a Bill (1975), available at http://www.youtube.com/watch?v=tyeJ55o3E10.

127 Moravcsik, Constitutional Settlement, supra note 28, at 34 . He adds steps involving implementation by national officials and adjudication in case the law is challenged, id., but these are not strictly speaking part of the legislative process.

${ }^{128}$ Compare, e.g., Herbert Wechsler, The Political Safeguards of Federalism: The Role of the States in the Composition and Selection of the National Government, 54 Colum. L. Rev. 543 
Council, by contrast, simply is the Member State governments. When the Council meets to consider issues in particular policy areas, it is composed of the Member States' respective ministers for those areas. And when it meets as the Council of Europe, it is composed of the respective heads of state. ${ }^{129}$ Some scholars have concluded that [t]hese powerful structural safeguards for state interests make Euroskeptic fears of a European superstate utterly implausible."130

For much of the EU's history, legislation required unanimous approval in the Council, thereby giving each Member State a veto over policies that adversely affected its interests. ${ }^{131}$ Now, most EU legislation in the Union's more traditional fields of competence proceeds by "qualified majority." 132 This process requires that legislative proposals be approved by a supermajority of votes in the council, with each state's vote weighted according to population as assigned in the treaties. ${ }^{133}$ The Treaty of Lisbon now "defines a qualified majority as (1) the votes

(1954) (arguing that members of Congress do represent their states' institutional interests), with Larry D. Kramer, Putting the Politics Back into the Political Safeguards of Federalism, 100 Colum. L. Rev. 215 (2000) (denying that members of Congress care about the institutional interests of state governments but claiming that political parties facilitate representation of those interests in national councils), with Lynn A. Baker \& Ernest A. Young, Federalism and the Double Standard of Judicial Review, 51 Duke L. J. 75, 106-33 (2001) (criticizing "political safeguards" theories based on both congressional representation and political parties). Prior to the Seventeenth Amendment, ratified in 1913, U.S. Senators were elected by the state legislatures and thus directly accountable to their state governments. But even under that regime, it was debatable how responsive to the wishes of those governments senators actually were. See, e.g., Vikram David Amar, Indirect Effects of Direct Election: A Structural Examination of the Seventeenth Amendment, 49 Vand. L. Rev. 1347, 1353-55 (1996) (noting that pre-17th Amendment senators were often thought to be more beholden to corrupt interests, and that in any event many states had enacted regimes of de facto direct election by the people).

${ }^{129}$ See Moravcsik, Without Illusions, supra note 3, at 35. This structure may actually encourage delegation of lawmaking upward from the Member States to the EU, for the reason that national executives who confront political opposition to particular initiatives at home may be able to circumvent that opposition by "kicking the decision upstairs" to the Council, where the executive represents the entire government of the Member State. See, e.g., Young, European Union, supra note, at 1691-92; Giandomenico Majone, Europe's 'Democratic Deficit': The Question of Standards, 4 Eur. L. J. 5, 7 (1998). American presidents occasionally try something similar by signing treaties, such as the U.N. Arms Trade Treaty, which may impose obligations that the President would have a hard time getting through Congress. See, e.g., Kerry Signs UN Arms Treaty, Senators Threaten to Block It, FoxNews.com, Sept. 25, 2013, available at http://www.foxnews.com/politics/2013/09/25/kerry-signs-un-arms-treaty-senators-threaten-toblock-it/. Such treaties usually face bleak ratification prospects in the Senate, although the mere act of signing is thought to impose certain legal obligations even without ratification. See Curtis A. Bradley \& Jack L. Goldsmith, Foreign Relations Law: Cases and Materials 356-57 (5th ed. 2014).

${ }^{130}$ Keleman, Durability, supra note 27, at 56.

${ }^{131}$ [cite Von Middelaar]

${ }^{132}$ See, e.g., Sieberson, supra note 116, at 922 ("Additional majority voting has been a feature of all major amendments to the treaties during the Union's first half- century, but the extension of QMV into new fields has always aroused controversy.").

${ }^{133}$ See Sieberson, supra note 116, at 936-40 (describing the evolution of the qualified majority procedure). 
of fifty-five percent of the Member States, (2) representing at least fifteen states, and (3) representing sixty-five percent of the EU population."134 This procedure prevents a single state, or even a small coalition of the largest states, from blocking legislation. ${ }^{135}$ In principle, the advent of qualified majority voting is a development of enormous significance. As Luuk van Middelaar has observed, "the transition from decision-making by unanimity to decision-making by majority [is the point at which] the whole became greater than the sum of its parts."136

That said, there is reason to question the practical significance of this change. As the Economist put it, "the EU almost never votes. The council of ministers is not some parliament where late night decisions can fall on a single vote, leaving whips counting every last member of their party through the division lobbies. The EU vastly prefers to take decisions by consensus." "137 In 2008, for example, the Council took 147 decisions, of which 128 were unanimous. ${ }^{138}$

On the other hand, 19 of those decisions were not unanimous. Gone are the days of the Luxembourg Accords, under which the Member States largely agreed to allow a single state to block qualified majority voting in the name of its vital interests. ${ }^{139}$ The bottom line is that the Council operates under strong norms of consensus, but the formal, law-based guarantees of consensus have substantially eroded. Recent American experience concerning the elimination of Senate filibusters for most presidential nominations demonstrates that norms of consensus may evaporate when political divisions become bitter and entrenched, paving the way for power politics in which the hard-wired legal voting rules are the only ones

${ }^{134}$ Id. at 939. See Lisbon TEU, art. 16(4). By moving to percentages of overall population as the formula for determining a majority on any given vote, the EU hopefully has spared itself the need to recalibrate the weighting of the votes in each new accession treaty, as well as fights over how often to re-allocate those votes if there should be no new accessions for an extended period of time. See, e.g., Baker v. Carr, 369 U.S. 186 (1962) (considering challenge to Tennessee's failure to reapportion representation in the state legislature for an extended period as a denial of equal protection of the laws). One may still expect disputes, however, over the methods and accuracy of the census by which population is determined. $C f$. Dept. of Commerce v. U.S. House of Representatives, 525 U.S. 316 (1999) (considering whether the Census Clause of the Constitution and the federal Census Act permitted the use of statistical sampling in the census).

135 The treaty expressly provides that, even if the population threshold for passage is not met, a any blocking coalition must include at least four Member States. See Lisbon TEU art. 16(4).

${ }^{136}$ Van Middelaar, supra note 111 , at 37.

${ }^{137}$ Charlemagne, Why Voting Weights Don't Matter, The Economist, Jun. 15, 2007, available at http://www.economist.com/blogs/certainideasofeurope/2007/06/why_voting_weights_dont_matter ; see also Van Middelaar, supra note 111, at 41 ("[T]o this day most decisions - and certainly the more important-are taken on the basis of consensus between the member states.").

138 Wikipedia, Voting in the Council of the European Union, http://en.wikipedia.org/wiki/Voting in the Council of the European_Union\#Treaty of Lisbon .282014_onwards.29 (visited Feb. 8, 2014).

139 See Van Middelaar, supra note 111, at 62-79. The treaties of Amsterdam and Lisbon did retain an "emergency brake" procedure whereby a single state could request that an issue be referred to the European Council based on "vital and stated reasons of national policy," id. at 79, but the referral does not appear to be automatic. 
that matter. ${ }^{140}$ The EU has seen constitutional "hardball" before, and it may well see it again. ${ }^{141}$

For now, however, there is little doubt that the "political safeguards of federalism"- that is, checks on the full exercise of the center's allocated competences derived from the incorporation of peripheral voices in the central political process - are much stronger in the EU than in the United States. ${ }^{142}$ The strength of those safeguards no doubt goes a long way toward explaining why the Member States were willing to grant such broad powers to the center in the first place. Concerns about the scope of EU competences have grown as formal unanimity has given way to qualified-majority voting. ${ }^{143}$ But the clout that Member States exercise in the Council continues to offer strong support for an intergovernmental view of the EU legislative process.

The intergovernmental view seems even stronger when it comes to administrative and fiscal capacity. The EU is, as Daniel Ziblatt notes, "fiscally speaking, a political pygmy; its actual budget is minuscule, and it is arguably the largest political unit in history without the power to raise debt for itself." ${ }^{144} \mathrm{EU}$ revenue comes predominantly from three sources: duties on imports, collected by the Member States and transferred to the EU; a share of the value-added tax collected by the Member States; and a levy on the gross national income of each

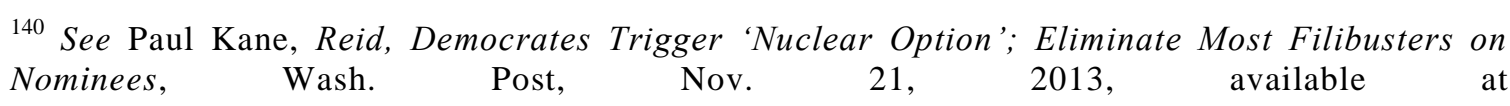
http://www.washingtonpost.com/politics/senate-poised-to-limit-filibusters-in-party-line-vote-thatwould-alter-centuries-of-precedent/2013/11/21/d065cfe8-52b6-11e3-9fe0-

fd2ca728e67c_story.html. This would be another example of Professor Tushnet's “constitutional hardball." See supra note 82.

141 See, e.g., Van Middelaar, supra note 111, at 58 (discussing France's "politics of the empty chair").

142 To put the situation in terms of American legislative procedure, the current state of EU legislation seems analogous not simply to a pre-Seventeenth Amendment U.S. Senate, in which the Senators are selected by the state legislatures, but rather one in which those legislatures also have an absolute right to instruct their Senators on particular votes and in which each Senator has a "blue slip"-like veto over not only nominees to office, as in this country, but much legislation. Again, the puzzle is that so much EU legislation is produced under these conditions.

${ }^{143}$ See Smits, supra note 87 (discussing initiatives by both the English and Dutch governments to review the allocation of competences between the Union and its Member States). The euro crisis, moreover, seems to have dampened enthusiasm for further expansion of EU competences. See Pisani-Ferry, supra note 22, at 175 (observing that, in the crisis's aftermath, "governments in Europe have limited esteem for the European institutions . . . and they are very reluctant to transfer competences and powers to Brussels").

144 Daniel Ziblatt, Between Centralization and Federalism in the European Union, in Paule E. Peterson \& Daniel Nadler, eds., The Global Debt Crisis: Haunting U.S. and European Federalism 113, 113 (2014); see also Moravcsik, Constitutional Settlement, supra note 28, at 35 ("Redistributing wealth by taxation and spending is the preeminent activty of the modern state, yet the EU does little of this."). The EU's "Europea" website is eager to make clear that "[n] ational governments are responsible for raising taxes and setting tax rates. The amount of tax you pay is therefore decided by your national government, not the EU." Taxation, europa.eu, http://europa.eu/pol/tax/index_en.htm (visited Feb. 9, 2014).. 
Member State capped at slightly under 1.3 percent. ${ }^{145}$ The last of these-which is simply a transfer from Member State budgets to the central authority-now accounts for about sixty percent of EU revenue. ${ }^{146}$ In this, the EU looks much like America under the Articles of Confederation (although without the incessant failures by the American states to actually pay their contributions ${ }^{147}$ ). None of this yields a great deal of revenue, and even the duties and VAT components are not structured in such a way as to allow the EU much flexibility to pursue regulatory objectives through the tax code. ${ }^{148}$

Consonant with these modest revenues, the EU accounts for only about two percent of European public spending; the U.S. national government, on the other hand, collects roughly 70 percent of American tax revenue. ${ }^{149}$ Most of the EU budget goes to the common agricultural policy and transfers to developing regions; "[1]ittle room exists for discretionary spending by Brussels technocrats." 150 The lack of broad fiscal powers sharply constrains the sorts of policies that the EU can enact and, therefore, the functions that Brussels can "take over" from the Member States. As Giandomenico Majone has suggested, lack of fiscal authority effectively limits the EU to regulatory policies, as opposed to non-regulatory or benefits-based programs. ${ }^{151}$ These fiscal constraints also deprive the EU institutions of a tool frequently used by Congress to regulate outside the scope of its enumerated authority, which is the ability to make large financial grants to state governments conditioned on the implementation of federal policies that Congress could not enact directly. ${ }^{152}$ And as I discuss further below, the EU's budgetary constraints leave few opportunities to win the loyalty of European citizens by

${ }^{145}$ See, e.g., European Commission, European Public Finance 237-42 (4th ed. 2008).

${ }^{146}$ See id. at 238.

${ }^{147}$ On the failure of the states to pay their "requisitions," see Calvin H. Johnson, Righteous Anger at the Wicked States: The Meaning of the Founders' Constitution (2009).

${ }^{148}$ Compare, e.g., Nat'l Federation of Independent Business v. Sebelius, 132 S. Ct. 2566 (2012) (holding that Congress could employ its taxing power to encourage individuals to purchase health insurance); United States v. Kahriger, 345 U.S. 22 (1953) (noting that the Court had upheld a wide variety of taxes with regulatory effects).

149 See Moravcsik, Constitutional Settlement, supra note 28, at 35; see also Pisani-Ferry, supra note 22, at 153 (noting that Europe "is not equipped with a meaningful federal budget").

${ }^{150}$ Moravcsik, Constitutional Settlement, supra note 28, at 35.

151 See Giandomenico Majone, The European Commission as Regulator, in Giandomenico Majone, ed., Regulating Europe 61 (1996); see also Pisani-Ferry, supra note 22, at 157 (identifying difficulties in creating a larger budget for the Euro zone or the EU as a whole).

152 See, e.g., South Dakota v. Dole, 483 U.S. 203 (1987) (upholding Congress's requirement that states raise their minimum drinking age to 21 as a condition on receipt of a portion of federal highway funds). 
providing essential benefits analogous to American programs like Social Security or Medicare. ${ }^{153}$

\section{Administrative Capacity and Implementation}

Shifting focus to the EU's administrative capacity reveals a similar picture. As Professor Moravcsik points out, "the notion of a European 'superstate' swarming with Brussels bureaucrats is a delusion (or deception) of Euroskeptics." 154 The European Commission, the principal administrative arm of the EU, employed 32,666 people in 2013 - which made it about half the size of the U.S. Social Security Administration and a slightly smaller employer than the City of Chicago. ${ }^{155}$ Outside certain key institutions like the European Central Bank or the Commission's Competition Directorate, the overwhelming responsibility for enforcing EU law falls to the Member States. ${ }^{156}$

This fact raises one of the most interesting contrasts in comparative federalism. A key exception to the U.S. Supreme Court's generally laissez faire approach to constitutional federalism is the anti-commandeering doctrine, which holds that Congress may not "commandeer" the states to implement federal law. ${ }^{157}$ Nonetheless, although American doctrine forbids requiring the States to implement national law, it remains the case that much federal law is implemented by the States as a voluntary matter. ${ }^{158}$ Hence, the American literature on "cooperative federalism" 159 _ whereby State officials dominate the implementation of federal law concerning education, social welfare, environmental protection, and other crucial areas-may shed some light on the importance of Member State implementation in Europe.

${ }^{153}$ Even in the area of farm policy, where most of the EU's money goes, national payments still outstrip benefits to farmers from the EU. See Moravcsik, Constitutional Settlement, supra note 28 , at 36 .

${ }^{154}$ Moravcsik, Constitutional Settlement, supra note 28, at 36.

155 Compare European Commission, HR Key Figures Card: Staff Members, 2013, available at http://ec.europa.eu/civil_service/docs/hr_key_figures_en.pdf, with Wikipedia, Social Security Administration, http://en.wikipedia.org/wiki/Social_Security_Administration (visited Feb. 9, 2014) (listing 65,000 employees); City of Chicago, 2013 Budget Overview, http://www.cityofchicago.org/content/dam/city/depts/obm/supp_info/2013\%20Budget/2013Overv iew.pdf, at 23 (visited Feb. 9, 2014) (proposing 33,550 employees in 2013).

156 See Moravcsik, Constitutional Settlement, supra note 28, at 36. Professor Moravcsik also notes the EU's general lack of "coercive capacity": "the EU has no police, no army, no significant intelligence capacity - and no realistic prospect of obtaining any of them." Id. at 35.

${ }^{157}$ See Printz v. United States, 521 U.S. 898 (1997) (holding that Congress could not require state executive officials to implement a federal gun control law); New York v. United States, 505 U.S. 144 (1992) (holding that Congress could not require state legislatures to implement a federal regulatory scheme for radioactive waste).

158 See, e.g., John D. Nugent, Safeguarding Federalism: How States Protect Their Interests in National Policymaking 168-212 (2009).

159 See, e.g., Philip J. Weiser, Towards a Constitutional Architecture for Cooperative Federalism, 79 N.C. L. Rev. 663 (2001); Young, Dual Federalism, supra note 40, at 44-46 (contrasting "cooperative federalism" with other federalism models). 
In particular, Heather Gerken and Jessica Bulman-Pozen's work on "uncooperative federalism" tends to highlight the ways in which the implementation power may promote local autonomy. ${ }^{160}$ In contrast to the "power of the sovereign," Professors Gerken and Bulman-Pozen emphasize the "power of the servant" 161 - that is, of the official charged with implementing a regulatory directive. This power stems from several sources. These include the "dependence" of the federal government on state officials to administer federal programs, which gives state officials both "leverage" and "discretion in choosing how to accomplish [their] tasks and which tasks to prioritize." ${ }^{162}$ State officials also derive power from their "integration" into federal regulatory schemes; "[w] actor is embedded in a larger system," Bulman-Pozen and Gerken argue, "a web of connective tissues binds higher- and lower-level decisionmakers. Regular interactions generate trust and give lover-level decisionmakers the knowledge and relationships they need to work the system."163 Finally, Bulman-Pozen and Gerken note that state officials "serve two masters" in the sense that although they are implementing federal policy, "their constituencies are based within the state." 164 This gives state officials both the incentive and the power to challenge federal officials, because they are not beholden to federal officials for their positions and have alternative sources of resources. ${ }^{165}$

In the United States, this power of the servant may be undermined by the option retained by the federal government to implement national laws on its own, with federal personnel. If state officials do not implement the Clean Air Act in a manner that meets federal standards, for example, the federal Environmental Protection Agency can retract its delegation of implementation authority to the states and operate the program directly. ${ }^{166}$ Resumption of direct federal implementation is costly, but because the federal government largely dominates the tax base the additional outlay is hardly out of the question. In Europe, by contrast, the authority and infrastructure to regulate directly from Brussels generally will not exist, nor will the ability to raise revenue to support such an expansion of authority. One would expect, then, the phenomenon of "uncooperative federalism" to operate even more strongly in Europe. And indeed the EU has often structured its more intrusive policies so as to build in a range of

\footnotetext{
${ }^{160}$ Jessica Bulman-Pozen \& Heather K. Gerken, Uncooperative Federalism, 118 Yale L. J. 1256 (2009); see also Nugent, supra note 158, at 168-212; Larry Kramer, Understanding Federalism, 47 Vand. L. Rev. 1485, 1542-46 (1994).

${ }^{161}$ See Bulman-Pozen \& Gerken, supra note 160, at 1265-71.

${ }^{162}$ Id. at 1266 .

${ }^{163} I d$. at $1268-69$.

${ }^{164} I d$. at 1270.

${ }^{165}$ Id. at 1270-71. See also Ernest A. Young, A Research Agenda for Uncooperative Federalists, 48 Tulsa L. Rev. 427 (2013) (raising questions about state officials' role in implementing federal law).

${ }^{166}$ See generally John P. Dwyer, The Practice of Federalism Under the Clean Air Act, 54 Md. L. Rev. 1183 (1995).
} 
acceptable implementation options up front. As Professor Moravcsik points out, "the single currency, the Schengen arrangement, and foreign policy cooperation . . . tend not to bind all members of the EU to a common standard, but to permit a level of internal flexibility unheard of in modern national governance." 167 On the most controversial measures — such as Schengen or the Euro-this flexibility has included the option not to participate at all.

A final development may offset this "uncooperative federalism" dynamic in Europe, however. One way around limitations on public enforcement of lawwhether originating in a subunit's opposition or simply in limited public enforcement resources - is to permit private parties to enforce that law on their own. In the U.S., "private attorneys general" play a critical and pervasive role in the enforcement of federal law, from antitrust and civil rights laws to environmental and securities statutes. ${ }^{168}$ Allowing private plaintiffs to enforce national law through civil litigation not only takes advantage of private resources, it also breaks the monopoly that federal and state executive officials would otherwise have on the enforcement of those statutes. Private incentives and resources may ratchet up enforcement levels under particular statutory regimes to levels that public officials, exercising their discretion, might find undesirable; likewise, private interests may favor expansive interpretations of national law that would be politically untenable for federal (and especially state) bureaucrats.

Daniel Kelemen has recently demonstrated a similar phenomenon in Europe, which he describes as a turn to "eurolegalism". ${ }^{169}$ Precisely because the central governmental apparatus has such weak enforcement capacity, Professor Kelemen argues, European law is increasingly recognizing American-style private rights of action to enforce EU mandates. ${ }^{170}$ "Across policy areas ranging from employment discrimination to consumer protection to antitrust to securities regulation to the free movement rights of workers, students, and even medical patients," Kelemen writes, "we can observe more coercive legal enforcement, more rights claims, and a growing judicial role in shaping policy." 171 Private enforcement thus overcomes "the absence of a Eurocracy powerful enough to enforce EU law from Brussels." 172 To the extent that this trend continues, it may well undermine the security that the EU's generally bare-bones enforcement appartus affords to Member State autonomy.

\footnotetext{
${ }^{167}$ Moravcsik, Constitutional Settlement, supra note 28, at 34.

168 See, e.g., William B. Rubenstein, On What a "Private Attorney General" Is-And Why It Matters, 57 Vand. L. Rev. 2129 (2004).

${ }^{169}$ R. Daniel Kelemen, Eurolegalism: The Transformation of Law and Regulation in the European Union (2011).

${ }^{170}$ See id. at 8.

${ }^{171}$ Id. at 5 .

${ }^{172}$ Id. at 8; see also id. at 41-79 (documenting changes in European legal procedures and legal culture that facilitate private enforcement of European law).
} 


\section{Identity}

The last aspect of the European order tending to support the intergovernmental viewpoint is the strong tendency of Europeans to identify primarily with their national political communities. ${ }^{173}$ In the United States, where the overhwelming majority of Americans identify quite strongly with the nation, the interesting questions concern whether they identify with their States as well. ${ }^{174}$ We certainly have Americans; do we still have Vermonters, Californians, or North Carolinians? ${ }^{175}$ Other observers have acknowledge a division of loyalties within the American political community, but questioned whether it breaks down along state lines. ${ }^{176}$ Europe has the opposite problem: Citizens strongly identify with their Member States-as Frenchmen, Germans, or Poles-but it is not clear they think of themselves as "Europeans." 177 Both the Maastricht and Lisbon treaties bow to this reality by stating explicitly that "[t]he Union shall respect the national Identities of its Member States." 178

${ }^{173}$ See, e.g., Kaelble, supra note 101, at 205-08 (collecting evidence); Van Middelaar, supra note 111, at 212-25 (noting the problem and discussing different historical strategies for overcoming it). It is worth remembering, however, that "national" and Member State identities are not necessarily the same thing. See Besselink, supra note 72, at 42 (noting that "[s]ome of the Member States are multinational, such as Spain, and the UK"). There is good reason to think that European integration has empowered separatist tendencies within several Member States, see Larry Siedentop, Some Unintended Consequences of Integration, in Luuk van Middelaar \& Philippe Van Parijs, eds., After the Storm: How to Save Democracy in Europe 67, 69-72 (2015), although that dynamic is largely outside the scope of this essay.

${ }^{174}$ Compare, e.g., Feeley \& Rubin, supra note 16, at 16 (assuming, without evidence, that they do not), with Ernest A. Young, The Volk of New Jersey? State Identity, Distinctiveness, and Political Culture in the American Federal System, unpublished manuscript (April 2015), available at http://scholarship.law.duke.edu/faculty_scholarship/3431/ (arguing that often Americans do identify with their states as well as with the nation).

${ }^{175}$ We definitely still have Texans. See, e.g., Wayne Thorburn, Red State: An Insider's Story of How the GOP Came to Dominate Texas Politics 2 (2014) (observing that many people "think of themselves first and foremost as Texans").

${ }^{176}$ See, e.g., Bill Bishop, The Big Sort: Why the Clustering of Like-Minded America is Tearing Us Apart (2008) (arguing that identity breaks down neighborhood by neighborhood); Colin Woodard, American Nations: A History of the Eleven Rival Regional Cultures of North America (2011) (arguing for strong regional identities based on historical migration patterns).

${ }^{177}$ See, e.g., Anthony D. Smith, National Identity and the Idea of European Unity, 68 Int'l Affairs 55 (1992).

178 TEU art. 6(3) (Maastricht). The Lisbon treaty is considerably more specific and adds an institutional dimension:

The Union shall respect the equality of Member States before the Treaties as well as their national identities, inherent in their fundamental structures, political and constitutional, inclusive of regional and local self-government. It shall respect their essential State functions, including ensuring the territorial integrity of the State, maintaining law and order and safeguarding national security. In particular, national security remains the sole responsibility of each Member State. 
Thomas Risse's collection of survey data indicates that very few individuals identify themselves as either exclusively or primarily European. The numbers, which were quite stable over the period between 1992 and 2004, hovered around ten percent for these two categories combined. ${ }^{179}$ This does not necessarily translate into widespread dislike or distrust of the EU. For much of the Union's history, "[a] strong and stable majority of Europeans [has supported] EU integration." 180 And even when polling data have indicated "a level of skepticism about both the EU and about political institutions in general," the EU institutions have been "clearly more trusted by Europeans than national parliaments and governments.",181

This broad support appears to have weakend considerably in the wake of the euro crisis, however. A 2013 Pew Research Center survey found that "[t]he favorability of the EU has fallen from a median of $60 \%$ in 2012 to $45 \%$ in 2013," with particularly precipitous declines in France and Spain. ${ }^{182}$ The same survey found that " $\mathrm{t}]$ he prolonged economic crisis has created centrifugal forces that are pulling European public opinion apart, separating the French from the Germans and the Germans from everyone else." ${ }^{183}$ It is far too early to say whether the

Lisbon TEU art. 4(2); see also id. art. 3 (providing that the EU "shall respect its rich cultural and linguistic diversity, and shall ensure that Europe's cultural heritage is safeguarded and enhanced"). See generally Besselink, supra note 72, at 40-44 (discussing these provisions).

179 See Thomas Risse, A Community of Europeans? Transnational Identities and Public Spheres 40-41 (2010); see also Kelemen, Durability, supra note 27, at 59-60 (reporting similar findings). The latest Eurobarometer polls are largely consistent with Professor Risse's findings, although they seem to indicate a further erosion of EU identity. Posing the question "Do you see yourself as ...?", the Spring 2015 survey found that 38 percent of Europeans answered only in terms of their nationality; 52 percent cited their nationality, followed by "European"; 6 percent placed "European" before their nationality; and only 2 percent identified solely as "European.": European Citizenship, Standard Eurobarometer 83, at 21 (Spring 2015), available at file:///C:/Users/ey14/Downloads/eb83 citizen_en.pdf. There are, of course, significant drawbacks to relying on survey data in this area. See, e.g., Smith, supra note 177, at 57 (warning that "[i]n few areas is the attitude questionnaire of such doubtful utility as in the domain of cultural values and meanings"); Checkel \& Katzenstein, supra note 14, at 10 (suggesting that "survey questions may create the attitudes they report, since people wish to provide answers to questions that are posed").

${ }^{180}$ Moravcsik, Constitutional Settlement, supra note 28, at 38.

${ }^{181}$ Id. at 39; see also Kaelble, supra note 101, at 209 (noting that "in recent years, trust in and expectations of specific policies of the EU have been stronger than overall identification with the EU"). In contrast, recent survey data in the U.S. shows the national government consistently scoring lower than state and local governments in terms of trust. See Pew Research Center, Beyond Distrust: How Americans View Their Government, at 59 (Nov. 2015), available at http://www.people-press.org/files/2015/11/11-23-2015-Governance-release.pdf.

${ }^{182}$ Pew Research Center, The New Sick Man of Europe: the European Union, May 13, 2013, at 1, available at http://www.pewglobal.org/files/2013/05/Pew-Research-Center-Global-AttitudesProject-European-Union-Report-FINAL-FOR-PRINT-May-13-2013.pdf. Similarly, solid majorities opposed conferring additional powers on Brussels, except in Germany and Italy. See $i d$. at 24 .

${ }^{183} \mathrm{Id}$; see also id. at 25, 30-31 (tracking diverging public attitudes on mutual assistance and trust of other member states). 
impact of the euro crisis on public confidence will be enduring. But if "identity" means, in William Mackenzie's elegant phrase, "in what context do 'I' properly use the word "we'?", ${ }^{184}$ then for most Europeans, "we" is not "Europe" or "the EU."185

Identity plays a number of roles in federal systems. Some have argued that a common sense of civic identity is necessary for democracy and community "will formation." 186 Europeans may also need a sense of common identity if they are to be asked to make sacrifices on behalf of one another. ${ }^{187}$ Germans are much more likely to support financial aid to Greeks or Portuguese, for example, if they all feel a common bond as "Europeans." It overlaps conceptually with loyalty; as I have argued elsewhere, loyalty entails a sense of identity with the community that does not depend on complete congruence between the community's policies and one's own preferences. ${ }^{189}$ In Albert Hirschman's seminal analysis of responses to dissatisfaction in communities, loyalty plays the critical role of retarding exit and motivating voice. ${ }^{190}$ It is often, in the short term, an irrational response; loyalty is a refusal to exit even when doing so might favor one's immediate interests. But commitment to a community or an institution may bring benefits in the medium to long term, especially if - as Professor Hirschman argues-a demonstration of loyalty may enhance one's voice within that community. ${ }^{19}$

\footnotetext{
${ }^{184}$ William James Millar MacKenzie, Political Identity 12 (1978).

${ }^{185}$ See Van Middelaar, supra note 111, at 217 (Europe's "transition from legal fact to political fact ... will be judged successful when Europe's political representatives can claim to speak and decide on behalf of a collective "we' .... The 'we' is not yet in prospect."); Simon Kuper, A Question of Identity, Fin. Times, Nov. 23, 2012, available at http://www.f t.com/cms/s/2/34783668-3370-11e2-aa83-00144f eabdc0.html ("Nobody ever ran into the street drunk, waving the European flag.").

${ }^{186}$ See, e.g., Jürgen Habermas, The Crisis of the European Union: A Response 46 (Ciaran Cronin trans. 2012). For a skeptical view of the possibility of democratcy at the European level, see Robert A. Dahl, Is International Democracy Possible? A Critical View, in Sergio Fabbrini, ed., Democracy and Federalism in the European Union and the United States, 194 (2005).

187 See, e.g., Martha Nussbaum, Political Emotions: Why Love Matters for Justice 3 (2013) (suggesting that emotional bonds of communal loyalty are necessary "to engender and sustain strong commitment to worthy projects that require effort and sacrifice-such as social redistribution, the full inclusion of previously excluded or marginalized groups, the protection of the environment, foreign aid, and the national defense"); David Miller, On Nationality 70-73 (1995) (suggesting that bonds of community help build support for redistributive policies). A similar sense of solidarity may also be necessary for a successful currency union. See PisaniFerry, supra note 22, at 34-35.

${ }^{188}$ See, e.g., Michael M. Bechtel, Jens Hainmueller, \& Yotam Margalit, Sharing the Pain: What Explains Public Opinion Towards International Financial Bailouts, MIT Political Science Working Paper No. 2012-5, April 2012.

189 See Ernest A. Young, Exit, Voice, and Loyalty as Federalism Strategies: Lessons from the Same-Sex Marriage Debate, 85 U. Colo. L. Rev. 1133, 1146-48 (2014).

190 See Albert O. Hirschman, Exit, Voice, and Loyalty: Responses to Decline in Firms, Organizations, and States 78 (1970).

${ }^{191}$ See Young, Federalism Strategies, supra note 189, at 1148-49.
} 
In the United States, citizen identification with subnational units enhances the likelihood that states will compete and innovate, ${ }^{192}$ and it powers the "political safeguards of federalism" by giving representatives in Washington, D.C., a reason to care about and act to protect the prerogatives of state governments back home. ${ }^{193}$ In the EU, on the other hand, loyalty to "Europe" might cause citizens in a particular Member State to oppose exit from the EU (or a watering-down of ties), even when they disagree with policies adopted at EU level. (It is worth remembering that in the EU, unlike America, the ultimate option of secession remains on the table. ${ }^{194}$ )

To be sure, social identity is not necessarily a zero-sum game. Americans tend to focus on episodes like Robert E. Lee's tragic choice of his beloved Virginia over his allegiance to the United States, which had actually offered him command of the Union army at the outset of the Civil War. ${ }^{195}$ We accordingly worry that identity with one's particular State will undermine one's loyalty to the nation. In so doing, however, we ignore another tradition in thinking about loyalty exemplified by Edmund Burke's notion that "[t]o be attached to the subdivision, to love the little platoon we belong to in society, is the first principle . . of public affections. It is the first link in the series by which we proceed toward a love to our country and to mankind." 196 A variety of contemporary observers agree that most individuals hold multiple social identities at once. ${ }^{197}$ Hence it is at least possible, at Thomas Risse has observed, that "we can strongly identify with our region, our nation-state, and feel loyalty toward the EU." 198

The survey data bear out this possibility. Professor Risse finds that "[a]lthough very few people exclusively identify with Europe or prioritize Europe over their nation-state, 40 percent to 50 percent on average feel attached to their

${ }^{192}$ See Hirschman, supra note 190, at 80 (arguing that loyalty encourages innovation).

${ }^{193}$ See Young, Volk of New Jersey, supra note 174; Jacob T. Levy, Federalism, Liberalism, and the Separation of Loyalties, 101 Am. Pol. Sci. Rev. 459, 464-65 (2007).

${ }^{194}$ Compare, e.g., Lisbon TEU art. 50 (explicitly recognizing a right of exit) with General Lee's surrender at Appomattox. As this chapter goes to press, there is significant concern that Britain will vote to depart the EU within the next several years. See, e.g., A Background Guide to "Brexit" from the European Union, The Economist, Oct. 19, 2015, available at http://www.economist.com/blogs/graphicdetail/2015/10/graphics-britain-s-referendum-eumembership.

${ }^{195}$ See Douglas Southall Freeman, Lee 109-12 (abridged ed. 1961) (1934).

${ }^{196}$ Edmund Burke, Reflections on the Revolution in France, 41 (J. G. A. Pocock ed., Hackett Pub. Co. 1987) (1790).

${ }^{197}$ See, e.g., Habermas, Crisis, supra note 186, at 47 ("Many loyalties overlap in the political life of a citizen, loyalties to which individuals attach quite different weights."); Anthony D. Smith, National Identity 4 (1991) ("[T]he self is composed of multiple identities and roles-familial, territorial, class, religious, ethnic and gender."); E. J. Hobsbawm, Nations and Nationalism since 1780: Programme, Myth, Reality 123 (1990) (observing that people have "several attachments and loyalties simultaneously, including nationality, and are simultaneously concerned with various aspects of life, any of which may at any one time be foremost in their minds").

${ }^{198}$ Risse, supra note 179 , at 23. 
nation and then to Europe." 199 Multiple identities may be particularly useful in federal systems. Alexander Hamilton explained in Federalist 28:

Power being almost always the rival of power, the general government will at all times stand ready to check the usurpations of the state governments, and these will have the same disposition towards the general government. The people, by throwing themselves into either scale, will infallibly make it preponderate. If their rights are invaded by either, they can make use of the other as the instrument of redress. ${ }^{200}$

Hamilton described a kind of checks and balances of the heart, in which popular loyalty is not ideally fixed, but fluid, shifting to one level of government or the other in response to the behavior of each. Even if one's loyalty to one level of government may be stronger than to another, this dynamic can operate as long as each level is a sufficiently plausible object of loyalty that, in the event of misbehavior by the one, the other can mobilize the allegiance of a dissatisfied populace. $^{201}$

The prospects for European identity depend on variables that are only imperfectly understood. The American Founders did not talk about identity, but they had a lot to say about loyalty. James Madison argued in Federalist 45 and 46 that citizens would prove loyal to the government that provided for their most basic, every-day needs. ${ }^{202}$ Likewise, contemporary political theorists have argued that a political community may constitute itself by the activity of deliberating and legislating as a community and observing a communal obligation to obey the laws. ${ }^{203}$ Similarly, European neofunctionalists predicted that citizens would come to identify with the EU for pragmatic reasons as the EU increasingly took responsibility for policies that benefited them. ${ }^{204}$ As Thomas Risse has demonstrated, public opinion data bears this prediction out-at least to some

199 Id. at 40-41. Professor Risse notes that these numbers "var[y] enormously among member states. On the one end of the continuum, we find citizens in Luxembourg (73.4\%), Italy (72.2\%), France $(70.3 \%)$, Spain $(68.2 \%)$, and Germany $(65.5 \%)$ who overwhelmingly describe themselves as Europeans, at least to some degree," while a significant majority of people in Great Britain, Finland, Sweden, Greece, and Austria "identify with their nation-state only." Id. at 41-42.

${ }^{200}$ Federalist No. 28, at 206 (Alexander Hamilton) (Isaac Kramnick ed., 1987) (1788).

201 See also Todd Pettys, Competing for the People's Affection: Federalism's Forgotten Marketplace, 56 Vand. L. Rev. 329 (2003).

${ }^{202}$ See The Federalist No. 45, at 296 (James Madison) (Isaac Kramnick ed. 1987) (1788); see also Young, Two Cheers, supra note 120, at 1368-69.

${ }^{203}$ See, e.g., Anna Stilz, Why Does the State Matter Morally, in Sigal R. Ben-Porath \& Rogers M. Smith, eds., Varieties of Sovereignty and Citizenship 244, 259-61 (2012).

${ }^{204}$ See, e.g., Ben Rosamond, Theories of European Integration 66 (2000). 
extent. ${ }^{205}$ And identity with Europe seems to be stronger among elites than among the people at large. ${ }^{206}$

The content of a universal European identity is not easy to pin down. ${ }^{207}$ Many invoke the EU's 1993 Copenhagen criteria, which describe the EU "as a community of liberal democracies and market economies governed by the rule of law and respecting human rights including minority rights." 208 It is not obvious how distinctive that formula is - the United States, after all, fits the same description. But distinctiveness and identity are not the same thing; after all, Tolstoy observed that all happy families are alike. ${ }^{209}$ In any event, there are other strands of pan-European identity formation that do not fit this modern, secular liberal mode. The entry into the EU of the states of Central and Eastern Europe, for example, has reinvigorated the notion of Christianity as a basic component of European identity. ${ }^{210}$

However, as Anthony Smith has observed, "national identifications possess distinct advantages over the idea of a unified European identity. They are vivid, accessible, well established, long popularized, and still widely believed, in broad outline at least." 211 Professor Smith concludes that, "[i]n each of these respects, 'Europe' is deficient both as idea and as process. Above all, it lacks a pre-modern past-a 'prehistory' which can provide it with emotional sustenance and historical depth." 212 Interestingly, the development of a European identity has responded to this difficulty in different ways within different Member States. Many Germans, for example, have come to view European identity in opposition to their own preWorld War II past, and those memories of ethnic nationalism and Nazi atrocities are certainly - to use Smith's terms- "vivid, accessible, well established, long popularized, and still widely believed." 213 The French, on the other hand, have tended to view Europe as an extension of their French identity - a "greater France" that offers the only realistic option for maintaining France's rightful place as a

${ }^{205}$ See Risse, supra note 179, at 90-91.

${ }^{206}$ See Kelemen, Durability, supra note 27, at 60-61.

207 Some accounts of what it means to be distinctively European look suspiciously like the preferences of American liberal academics. See, e.g., John McCormick, Same Same, But Different, The European.eu, Jan. 15, 2014, available at http://en.theeuropean.eu/johnmccormick/7856-the-importance-of-a-european-identity.

${ }^{208}$ Risse, supra note 179 , at 26.

${ }^{209}$ Leo Tolstoy, Anna Karenin 13 (Rosemary Edmonds, trans. 1978) (1873-1877).

${ }^{210}$ See Risse, supra note 179, at 209-13. This development, in turn, has difficult implications for Europe's ability to accept large numbers of non-Christian migrants.

${ }^{211}$ Smith, European Unity, supra note 179, at 62.

212 Id.

${ }^{213}$ See Risse, supra note 179, at 65-69. Or, as some research indicates, the Old Germany is "the other." See id. at 66. Professor Risse finds a similar phenomena in Spain's rejection of its fascist past under Franco. See id. at 69-71. 
political leader and cultural beacon on the world stage. ${ }^{214}$ And the Eastern European states tend to see a "return to Europe" as a reaffirmation of an earlier European identity suppressed under Soviet-imposed communism. ${ }^{215}$ In all these different ways, European identity can either build on or play off of more "vivid" national identities.

These dynamics reflect a broader tendency described by Professor Risse, which is that while there is little evidence of a robust "European" identity, supported by a pan-European public sphere, we do see a progressive "Europeanization" of national identities and national public spheres. ${ }^{216}$ In other words, people remain French, German, or Polish, and their debates continue to take place within distinct national environments. But national identities increasingly incorporate a European component, and public debates increasingly concern European issues and engage participants from outside the national sphere.

From an intergovernmental perspective, that may be enough. In this model, Member State governments need their publics to support the delegation of important functions to the EU, but since the Member States remain the primary actors it would seem fine-even salutary-that national identities remain primary. The primacy of national identity, moreover, serves as a critical "political safeguard" of member state autonomy in an intergovernmental scheme. As long as member states remain the primary font of legitimate political authority, no cession of policy authority to Brussels is likely to be irrevocable, and the truly salient decisions will be dominated by the politics of the national capitals.

Those who prefer some version of "ever closer union," on the other hand, tend to see the europeanization of national identity as a hopeful sign that the development of full-fledged European identity is possible. ${ }^{217}$ Jurgen Habermas, for example, argues that increasing labor immigration, growing ethnic, religious, and linguistic diversity, as well as mass tourism and the Internet "have rendered national borders porous"; he looks hopefully toward the development of a "Europe-wide civic solidarity" that would make meaningful democracy and redistributive sacrifice possible at the EU level. ${ }^{218}$ Nascent federalists thus press for ever more public engagement with EU processes and issues. ${ }^{219}$

${ }^{214}$ See Risse, supra note 179, at 71-76. This may be a fair way of characterizing how Texans feel about the United States.

215 See Risse, supra note 179 , at 76-81.

216 See also Kaelble, supra note 101, at 195 (noting that an emerging "European public sphere" is "[b]ased on a connected network of national rather than Europe-wide media" and "reflected in the simultaneous appearance of the same news in the media of different nation-states, presented from a European rather than a purely national perspective").

${ }^{217}$ See Risse, supra note 179, at 100-03.

${ }^{218}$ Habermas, Crisis, supra note 186, at 48-49, 53.

219 See id. at 49; Risse, supra note 179, at 237-41; see also Kelemen, supra note 169, at 252 (noting that " $[\mathrm{m}]$ any advocates of deeper European integration hope that citizen support for a 'Europe of rights' will bolster otherwise anemic levels of common identity and public support for European integration"). 
Intergovernmentalists like Professor Moravcsik, on the other hand, suggest that the EU performs best when it flies under the radar; to the extent that democratic publics pay attention to their supranational agents in Brussels, they are unlikely to like what they find. ${ }^{220}$

The conflict between an intergovernmental Europe with predominantly national identity and a federal one of "Europe-wide civic solidiarity" is put most starkly, of course, by the EU's recent crises over the euro, migration, and terrorism. Before turning to those crises, however, it will help to discuss the longer-term relationship between federalism and time.

\section{The Future of European Integration: Of Federalism and Time}

My goal in this essay is not to urge that either the federal or the intergovernmental perspective is the right one. Both accurately describe elements of the European legal and political order. It follows that it is perfectly appropriate, for example, to compare the EU's powers to those of a federal stateso long as one remembers that those powers are also limited by factors not common to federal states. In the remainder of this essay, I want to ask whether the current post-Lisbon settlement is likely to be stable. Professor Moravcsik, for example, argues that the EU now does basically the things that it makes sense for the EU to do; that extension of EU authority into areas like social provision would be both unworkable and unpopular; and that hence we are unlikely to see largescale changes in the absence of some sort of "exogenous shock."221 Other observers, however, have argued that federal regimes are "inherently unstable."222

I will consider here two possible reasons to doubt the stability of current arrangements. The first is what skeptics of national power in the United States might call "creeping nationalism"- and proponents of European federalism might call "ever closer union." The idea is that federal systems may have some sort of inherent tendency toward centralization over time. ${ }^{223}$ American history appears at first glance to provide some support for that notion. I will suggest, however, that this American historical tendency may not necessarily be replicated in Europe, mostly because of the different way in which the arc of centralization intersects with the arc of the growth of government generally in the two different contexts.

The second possibility arises from the possibility that some exogenous shock might upset the EU's current equilibrium. In the United States, the growth

\footnotetext{
${ }^{220}$ See Moravcsik, Constitutional Settlement, supra note 28, at 42-47.

${ }^{221}$ See Moravcsik, Constitutional Settlement, supra note 28, at 47.

${ }^{222}$ Kelemen, Durability, supra note 27, at 53.

${ }^{223}$ See, e.g., See, e.g., Dennis C. Mueller, Federalism and the European Union: A Constitutional Perspective, 90 Public Choice 255, 270 (1997). The other possibility, of course, is the EU may tend toward dissolution over time - a prospect that some observers consider considerably more likely than consolidation. See, e.g., Kelemen, Durability, supra note 27, at 54. I focus on centralization here both because that has been the primary focus of my own work on American federalism, see, e.g., Young, Making Federalism Doctrine, supra note 88, and because a centralizing teleology has been explicitly built into the EU treaties.
} 
of national power has often responded to various national crises. ${ }^{224}$ And Europe has recently experienced a series of crises, beginning with the Euro crisis and continuing with turmoil over mass migrations and terrorist attacks. Each of these crises has the potential to upset various aspects the EU's equilibrium - and in particular, each has placed pressure on the EU's rough balance between federalism and intergovernmentalism.

\section{A. "Ever Closer Union"?}

The history of American federalism is one of unrelenting centralization. Madison wrote in Federalist 45 that "[t]he powers delegated by the proposed Constitution to the federal government are few and defined," 225 but as Gary Lawson has observed, "the best laid schemes o' mice, men and framers gang aft agley." 226 From the establishment of the Bank of the United States, to the use of national power to expand American territory and settle the frontier, and the development of infrastructure necessary to prosecute the Civil War, to the development of a regulatory infrastructure in the Progressive era and a welfare bureaucracy under the New Deal and Great Society, as well as the expansion of the federal judicial role of enforcing federal civil rights and the development of a national security state, centralization of government power has proceeded in fits and starts but has almost always run in the same direction. ${ }^{227}$ Advocating constitutional limits on national power, by contrast, has long been an essentially rear-guard action, an effort to slow the growth of the national Leviathan rather than to actually roll it back. ${ }^{228}$ The Supreme Court's landmark decisions in United States v. Lopez ${ }^{229}$ and United States v. Morrison, ${ }^{230}$ for example, ended an era of judicial abdication with respect to enforcing the limits of Congress's enumerated

${ }^{224}$ Key episodes in development of national institutions and national identity include the Civil War and the Great Depression, for example.

${ }^{225}$ The Federalist 45, supra note 202, at 296.

${ }^{226}$ Gary Lawson, The Rise and Rise of the Administrative State, 107 Harv. L. Rev. 1231, 1233 (1994).

${ }^{227}$ This is not to overlook the significant expansion of governmental authority at the state level as well. See generally Stephen Gardbaum, New Deal Constitutionalism and the Unshackling of the States, 64 U. Chi. L. Rev. 483 (1997) (pointing out the growth of state governmental authority during the New Deal period). But the national expansion is far more dramatic, both proportionally and in absolute terms.

${ }^{228}$ See, e.g., Robertson, supra note 21, at 149-53 (recounting that even under conservative presidents ideologically committed to federalism, actual decentralization has been modest and offset by nationalization where that would lead to conservative ends); Lawson, supra note 226, at 1236 ("There is now virtually no significant aspect of life that is not in some way regulated by the federal government. This situation is not about to change.").

${ }^{229} 514$ U.S. 545 (1995) (striking down the federal Gun Free School Zones Act as outside the limits of Congress's authority under the Commerce Clause).

${ }^{230} 529$ U.S. 598 (2000) (striking down a portion of the federal Violence Against Women Act as outside the limits of the Commerce Power). 
powers, but the limits imposed in those and subsequent cases have not meaningfully cut back on national regulatory authority. ${ }^{231}$

American scholars either celebrate these developments or develop something of a fatalistic streak. It is easy to draw the inference that, as a general matter, federal systems have a tendency toward centralization of power. ${ }^{232}$ And it is equally easy to see evidence for that tendency in Europe. Certainly that was the original plan: advocates of integration in the "neofunctionalist" school sought to build constant centralizing pressure into the system. As Paul Craig as explained, they hoped that "[i]f there was integration in one sphere it would, therefore, create pressure for integration to proceed in other areas." 233 For example, "[i]f formal tariff barriers and quotas were removed with the object of facilitating the creation of a single market, this would in turn generate a need to deal with non-tariff barriers which could have an equally destructive impact on cross-border trade. This very same desire to create a single market with a level playing field as between the states would then lead to other matters being decided at Community level." 234 Likewise, neofunctionalists anticipated that "[i]n areas which had been integrated the relevant interest groups would then be expected to concentrate their attention on the Community level, consonant with the basic idea that 'you shoot where the ducks are' and apply pressure on those who have the regulatory power." 235 These same centralizing pressures have played a prominent role in American federalism for some time.

Although leading contemporary scholars of European integration have come to doubt important aspects of the neofunctionalist account, they acknowledge that "functional spillover created and continues to create some impetus for further integration."236 And students of European identity-formation have concluded that those who have been most able to avail themselves of the benefits of freedom of movement and the single market-typically, educated and

231 See, e.g., Gonzales v. Raich, (upholding Congress's authority to regulate medicinal, noncommercial use of marijuana); Ernest A. Young, The Rehnquist Court's Two Federalisms, 83 Tex. L. Rev. 1, 103-15 (2004) (explaining why the Supreme Court is unlikely to impose highlyconstraining limits on the Commerce Clause or Congress's other enumerated powers). For example, in the famous litigation over President Obama's healthcare legislation, the Court held that the mandate that all individuals must purchase health insurance fell outside Congress's Commerce Clause authority but nonetheless upheld that provision as a valid use of Congress's power to tax. See Nat'l Fed'n of Independent Business v. Sebelius, 132 S. Ct. 2566 (2012).

${ }^{232}$ See, e.g., Mueller, supra note 223, at 270 (noting "a tendency in all federalist systems for responsibility for government services to shift upward in the federalist hierarchy"). Dean Rubin and Professor Feeley, for example, argue that the nationalization of American institutions follows directly from the fading of distinctive state identities in the U.S. See Rubin \& Feeley, supra note 28 , at 126 .

${ }^{233}$ Craig, Nature of the Community, supra note 35, at 3.

${ }^{234} I d$.

${ }^{235}$ Id. at 4; see also Rosamond, supra note 204, at 58-59.

${ }^{236}$ Craig, Nature of the Community, supra note 35, at 5. 
mobile elites - are the most likely to identify primarily as "European" rather than as citizens of a particular Member State. ${ }^{237}$

Another factor driving centralization in European Law has been the teleological approach often taken by the European Court of Justice. In cases construing both the underlying treaties and the scope and effect of community legislation, the ECJ has employed a "preference for Europe" that tends to maximize the integrative effect of community law. ${ }^{238}$ American jurisprudence lacks any such frank acknowledgements of a driving teleology, but it is not hard to find similar impetuses in our constitutional law. It seems fair to say, for example, that the Marshall Court's pathmarking federalism decisions ${ }^{239}$ were driven by a common imperative to carve out institutional space for the infant national government.

Similar imperatives drove the expansive development of federal general common law in the Nineteenth Century, ${ }^{240}$ the post-Reconstruction expansion of federal judicial power, ${ }^{241}$ and the judge-driven incorporation of the Bill of Rights into the Fourteenth Amendment ${ }^{242}$ and the expansion of federal unenumerated rights. ${ }^{243}$ These developments were all "teleological" in the sense that a whole host of discrete interpretive questions were resolved in line with a general imperative to replace "parochial" state laws and courts with uniform national principles and federal judicial enforcement. ${ }^{244}$ The relevant questions concerned a wide array of constitutional provisions, federal statutes, and common law doctrines, but there is little doubt that many of the answers rested on an American version of "ever closer union."

The rationales for these American jurisprudential moves offer some insight into the forces pressing for centralization in modern federal systems. The

\footnotetext{
${ }^{237}$ See Fligstein, supra note 14, at 4.

${ }^{238}$ See, e.g., Craig, Competence, supra note 42, at [5]; Niall Fennelly, Legal Interpretation at the European Court of Justice, 20 Fordham Int'1 L. J. 656 (1997).

${ }^{239}$ See, e.g., McCulloch v. Maryland, 17 U.S. (4 Wheat.) 316 (1819); Gibbons v. Ogden, 22 U.S. (9 Wheat.) 1 (1824); Martin v. Hunter's Lessee, 14 U.S. (1 Wheat.) 1816); Cohens v. Virginia, 19 U.S. (6 Wheat.) 264 (1821); see generally Robert G. McCloskey, The American Supreme Court $35-52$ ( $4^{\text {th }}$ ed. 2005$)$.

${ }^{240}$ See, e.g., Swift v. Tyson, 41 U.S. (16 Pet.) 1 (1842) (holding that the general commercial law, not state law, governs commercial cases brought in the federal courts' diversity jurisdiction); Tony Freyer, Harmony and Dissonance: The Swift and Erie Cases in American Federalism (1981).

${ }^{241}$ See, e.g., Monroe v. Pape, 365 U.S. 167 (1961); Brown v. Allen, 344 U.S. 443 (1953).

${ }^{242}$ See, e.g., Everson v. Board of Education, 330 U.S. 1 (1947); Mapp v. Ohio, 367 U.S. 643 (1961); Duncan v. Louisiana, 391 U.S. 145 (1968).

${ }^{243}$ See, e.g., Griswold v. Connecticut, 381 U.S. 479 (1965); Lawrence v. Texas, 539 U.S. 558 (2003).

${ }^{244}$ See, e.g., Lucas A. Powe, Jr., The Warren Court and American Politics (2000) (arguing that the Warren Court's rights decisions were driven by a desire to bring social practices in the South and in Catholic enclaves in the North in line with national norms).
} 
expansion of the general federal common law, especially in the nineteenth century, reflected imperatives similar to the construction of Europe's internal market. The idea was that merchants and other commercial entities doing business across state lines (and therefore having access to the federal courts) should have recourse to a uniform set of commercial rules; that sort of uniformity, it was thought, would encourage the growth of an integrated and prosperous national market. ${ }^{245}$ The extended sequence of statutes and cases establishing a broad scope and preferred position for federal court jurisdiction, on the other hand, reflected a distrust of state institutions after the Civil War. Whereas the Founding era had seen state courts as the primary forums for resolution of legal disputes under both state and federal law, ${ }^{246}$ the late nineteenth and early twentieth century cases came to view the federal courts as essential vehicles for bypassing state parochialism and assuring the supremacy of federal law. ${ }^{247}$ Finally, the human rights cases display a strong dose of rights universalism; once a court defines a right as fundamental, it is hard not to mandate that all jurisdictions conform. ${ }^{248}$

These imperatives cash out somewhat differently in Europe. The drive for uniform legal rules to govern commerce in the single market has seen remarkable success, and as the neofunctionalists predicted the beneficiaries of this sort of uniformity have been among the strongest supporters of European integration. In contrast, European law generally has not sought to supplant or bypass Member State institutions, choosing instead to use those institutions as the primary vehicles for implementing and enforcing European law. ${ }^{249}$ I have already discussed the role

${ }^{245}$ See, e.g., Freyer, supra note 240, at 40-41; Randall Bridwell \& Ralph U. Whitten, The Constitution and the Common Law 87-97 (1977).

${ }^{246}$ See Hart \& Wechsler, supra note 69, at 22 (noting that the First Judiciary Act left cases arising under federal law largely to the state courts); Henry M. Hart, The Power of Congress to Limit the Jurisdiction of the Federal Courts: An Exercise in Dialectic, 66 Harv. L. Rev. 1362, 1401 (1953) (noting that "[i]n the scheme of the Constitution, [state courts] are the primary guarantors of constitutional rights").

${ }^{247}$ See, e.g., Monroe v. Pape, 365 U.S. 167 (1961); Ex parte Young, 209 U.S. 123 (1908); see also Hart \& Wechsler, supra note 69 , at 28 . Federal courts had the overwhelming support of national elites in their articulation of broad individual human rights in large part because the state courts were thought unlikely to recognize equivalent rights if left to their own devices. Indeed, once the tide turned in the federal courts in the 1980s, liberal icon Justice William Brennan famously called for the state courts to take the lead in articulating a broader vision of individual rights than the newly-conservative federal courts were likely to support. See William J. Brennan, Jr., State Constitutions and the Protection of Individual Rights, 90 Harv. L. Rev. 489 (1977).

${ }^{248}$ See, e.g., Palko v. Connecticut, 302 U.S. 319, 325 (1937) (stating that the guarantees fo the Bill of Rights would bind the states to the extent they are "implicit in the concept of ordered liberty"); Ernest A. Young, The Supreme Court and the Constitutional Structure 392-426 (2012) (discussing the theory and history of incorporation). That has proven true even on issues, such as the best way to prevent involuntary confessions under the Fifth Amendment, where the question seems more one of policy than of basic value. See, e.g., Miranda v Arizona, 384 U.S. 436, 523 24 (1966) (Harlan, J., dissenting) (protesting that states should be allowed to experiment concerning the most effective way to prevent involuntary confessions).

${ }^{249}$ See, e.g., Daniel Halberstam, Comparative Federalism and the Issue of Commandeering, in Kalypso Nicolaidis \& Robert Howse, eds., The Federal Vision: Legitimacy and Levels of Governance in the United States and the European Union 213, 214-15 (2001); see also Weiler, 
of Member State bureaucracies in enforcing European law, but this is also true on the judicial side. There is no parallel EU judicial system like the American federal judiciary, which includes the full array of administrative courts, trial courts of first instance, regional courts of appeal, and a Supreme Court. ${ }^{250}$ This institutional reality has in turn affected the development of European human rights jurisprudence. That jurisprudence has developed primarily in either national courts or in the distinct forum of the European Court of Human Rights, which continues to stand apart from the EU legal structure. ${ }^{251}$

To put the point more directly, America's national institutions benefit from enormous prestige among the business community (as the suppliers and enforcers of uniform rules ensuring a single national market) as well as the media and elite intellectuals (who look to federal law and institutions for the progressive regulation and social provision, as well as the development and enforcement of individual rights). Both groups tend to see the centralization of national authority as a response to a history of inaction or policy failures at the state level. ${ }^{252}$ For many in both groups, the States are annoying bastions of parochialismimpediments to commerce and havens of backward thinking on race and other issues. ${ }^{253}$ This view persists - and provides an impetus for further centralizationdespite the demonstrable role of States at the forefront of many progressive causes, from consumer safety regulation to same-sex marriage to environmental protection. $^{254}$

But it is not necessarily this way in Europe. While the EU has established itself as the protector of open and competitive markets, it has not also taken on the

supra note 41, at 2426 (noting how the ECJ was able to enlist national courts as allies in spurring the enforcement of EU law).

${ }^{250}$ On the institutional development of that system and its relationship to the state court systems, see generally Hart \& Wechsler, supra note 69; Justin Crowe, Building the Judiciary: Law, Courts, and the Politics of Institutional Development (2012).

251 [cite on ECHR] Advocates of "constitutional patriotism" as a form of European identity emphasize a common commitment to human rights rather than ethnic or religious commonality. It may undermine the development of such an identity that the primary exponent of a human rights jurisprudence in Europe, the ECHR, stands apart from the EU structure. The Treaty of Lisbon did formally adopt the Charter of Fundamental Rights of the European Union as part of EU law, but it remains to be seen whether this will supplant the European Convention on Human Rights as the key rights document in Europe.

${ }^{252}$ Robertson, supra note 21, at 112-16 (describing the origins in the New Deal in the failure of state governments to stem the tide of the Depression).

253 See, e.g., Linda Greenhouse, Trojan Horse, N.Y. Times, April 3, 2013, available at http://opinionator.blogs.nytimes.com/2013/04/03/trojan-horse/? php=true\& type=blogs \& r $=0$ (criticizing arguments for legalizing same-sex marriage as a matter of state law, rather than federal constitutional command, as retrograde); see also Baker \& Young, supra note 128, at 13362 (addressing normative arguments against limiting national power).

254 See, e.g., Heather K. Gerken, A New Progressive Federalism, Democracy, Spring 2012, available at http://www.democracyjournal.org/24/a-new-progressive-federalism.php?page=1; Kathleen M. Sullivan, From States' Rights Blues to Blue States' Rights: Federalism After the Rehnquist Court, 75 Fordham L. Rev. 799 (2006). 
role as the guardian of constitutionalism and human rights. That function remains primarily with the Member States. Jürgen Habermas thus insists that those states "survive within the federal polity in their freedom-guaranteeing function of constitutional states," with the responsibility to ensure that "the Union must not fall below the level of taming and civilizing state power already achieved in the states." ${ }^{255}$ So when the German Constitutional Court, as well as high tribunals in other member states, asserts the right to limit integration in the name of constitutional democracy, ${ }^{256}$ it can draw on institutional and political resources that no American state supreme court could assert.

A similar contrast is even more evident with respect to the institutions of the regulatory and welfare state. Regulatory and welfare institutions developed in the United States most prominently (although not exclusively) at the federal level, in part because of perceived inaction by the States. Hence, Franklin Roosevelt's New Deal occurred at the national level due to widespread inability of state and local governments to respond to the Depression; likewise, federal environmental regulation in the 1970 s responded to perceived neglect in most states. ${ }^{257}$ In Europe, by contrast, the Member States developed extensive regulatory and welfare institutions long before the foundation of the EU. Hence, while the EU dominates regulation providing for competition and open markets, Europeans look primarily to their Member States for other forms of regulation and for education, welfare, and other forms of social protection. ${ }^{258}$ Part of the explanation is surely temporal. Movements toward centralization in America occurred at roughly the same time as (and partly as a result of) pressures to expand the role of government generally and recognize a broader range of individual rights: the arcs of centralization and of the growth of government largely coincided. In Europe, the movement toward unification began well after much of the expansion of government generally had already taken place.

Institutional inertia thus plays a profoundly different role in Europe and the United States. Efforts to decentralize American government, such as Ronald Reagan's "New Federalism" in the 1980s, confront an entrenched federal regulatory and welfare bureacracy in which millions of people have a stake. It is small wonder that no serious effort to "roll back" these bureaucracies has ever gotten off the ground. ${ }^{259}$ In Europe, by contrast, the entrenched bureaucracies exist

${ }^{255}$ Habermas, Crisis, supra note 186, at 39 (emphasis in original); see also Joerges, supra note 71 , at 77 ("[N]ational constitutional courts remain entrusted with the guardianship over their national constitutions and are not prepared to subject the exercise of this authority to the CJEU.").

${ }^{256}$ See, e.g., Lisbon Treaty Case, BVerfGE 123 (343).

${ }^{257}$ See Robertson, supra note 21 , at 87-88.

${ }^{258}$ See Fligstein, supra note 14, at 5 ("European publics . . . . have consistently opposed allowing national welfare state policies such as unemployment benefits, pensions, and labor market policies to be decided in Brussels."); Moravcsik, Constitutional Settlement, supra note 28, at 4142.

259 See, e.g., Martha Derthick, Keeping the Compound Republic: Essays on American Federalism 36 (2001) (discussing Reagan's inability to make much headway). 
at the Member State level, and it is little surprise that EU governance must operate through them, rather than as an alternative.

Similar, but more profound, temporal differences explain why Europeans are likely to continue to identify primarily with their Member States for the foreseeable future. Many of the Member States have been independent nations for centuries, and although some-e.g., Italy, Germany-are considerably newer, they nonetheless date from roughly the same period in which nationalism became a major force in world affairs. ${ }^{260}$ This was approximately the same time period in which the United States transformed into a nation in the modern sense. ${ }^{261}$ Most of the American states have no history as independent political communities separate from the United States, and the experience of those that do was generally brief and unsatisfactory. ${ }^{262}$ Notwithstanding the spectacular success of the EU over the past half-century, these communal memories of nationhood will not yield easily.

The EU's division of labor between Member States and Brussels seems likely to reinforce this sense of identity, at least for the time being. The American authors of the Federalist papers argued that federal systems involve a vertical competition for the loyalties of the sovereign People, and that the advantage in this competition would rest with the government entrusted with functions that mattered to citizens in their everyday lives. ${ }^{263}$ Hence, the primacy of national identification in America has coincided with a shift in responsibility over bread-and-butter regulation (e.g., consumer safety, employee rights) and, most important, social provision from the states to the national government. In Europe, those functions remain with the Member States-a role solidified by the temporal development of their welfare states prior to the advent of the EU. As Professor Moravcsik points out, despite the volume of law emanating from Brussels most of it deals with matters of relatively low salience to private citizens. ${ }^{264}$

All of these points should counsel caution in assuming that Europe will see the same inexorable march toward centralization that we observe in American history. It is true that the scope of EU competences is already extremely broad, and it seems to expand with each new treaty. But it would be impossible to capitalize on that breadth without significantly increasing the governmental capacity of the Union, in terms not only of its fiscal and administrative resources but also of its ability to take truly autonomous decisions. And that sort of shift seems unlikely without any shift in citizens' primary identification tow ard the

\footnotetext{
${ }^{260}$ See, e.g., Daniel Zilblatt, Structuring the State: The Formation of Italy and Germany and the Puzzle of Federalism 1-2 (2006).

${ }^{261}$ See, e.g., Richard Franklin Bensel, Yankee Leviathan: The Origins of Central State Authority in America, 1859-1877 (1990).

${ }^{262}$ It should be unsurprising that most of the Confederacy, as well as the New England states that credibly threatened to secede during the War of 1812, had experienced a period of communal existence antedating their membership in the Union.

${ }^{263}$ See Federalist No. 28, supra note 200, at 208 (Hamilton); Federalist No. 45, supra note 202, at 294-97 (Madison); see also Pettys, supra note 201.

${ }^{264}$ See Moravcsik, Constitutional Settlement, supra note 28, at 26-27.
} 
Union. The same factors of inertia and tradition that impede any serious rollback of federal power in the United States press against each expansion of institutional power in Brussels.

\section{B. Shocks to the System: The Euro and Other Crises}

Professor Moravcsik has argued that the EU's current "constitutional settlement" is likely to be stable, "barring large exogenous shocks." 265 It is possible, however, that the Euro Crisis is that shock-or at least that it indicates the sort of disruptive factors that might undermine the current equilibrium. That crisis has revealed a disconnect between the Euro-zone's centralized monetary policy and its decentralized fiscal policy: Member States within the zone share a common currency, but they make their own taxing, spending, and borrowing decisions. ${ }^{266}$ For some time, analysts have disagreed vigorously as to whether this disconnect is sustainable over the long term. ${ }^{267}$ As the crisis has played out, the states of the Euro area have taken measures to strengthen central controls over Member States' fiscal policy in order to preserve the Euro's monetary union. ${ }^{268}$ The jury remains out as to whether the euro crisis will ultimately deepen the institutional basis of EMU or cause that monetary union to collapse; there is little doubt, however, that the crisis has already profoundly affected the EU's institutional structure. ${ }^{269}$

Likewise, 2015 saw the EU reeling under two additional and related crises. An "unprecedented" number of refugees from Syria, Libya, Iraq, sub-Saharan Africa, and other places flooded into Europe in 2015, "more than in any previous European refugee crisis since World War II." 270 Through the first nine months of the year, over 800,000 people claimed asylum in the EU. ${ }^{271}$ The influx impacted some Member States considerably more than others, and individual states varied

\footnotetext{
265 See Moravcsik, Constitutional Settlement, supra note 28, at 23; see also Fligstein, supra note 14, at 5 (suggesting, in 2008, that "European political, economic, and social integration may have reached a natural limit").

${ }^{266}$ See Alicia Hinarejos, Fiscal Federalism in the European Union: Evolution and Future Choices for EMU, 50 Common Mkt. L. Rev. 1621, 1624-25 (2013) (describing EMU as "asymmetric" for this reason); S. Fabbrini, supra note 4, at 25-26 (describing this mismatch as an element of the compromise between intergovernmental and federal views of the EU).

${ }^{267}$ See, e.g., Michael D. Bordo, Lars Jonung, \& Agnieszka Markiewicz, A Fiscal Union for the Euro: Some Lessons from History, 59 CESifo Econ. Stud. 449 (2013) (surveying the debate); Pisani-Ferry, supra note 22, at xi-xii..

${ }^{268}$ See, e.g., F. Fabbrini, Economic Governance, supra note 10, at 2-10.

${ }^{269}$ See, e.g., Joerges, supra note 255 , at $77-78$ (observing that "[w]ithin a timespan of half a decade, we have been witnessing the emergence of a new ordering of the Union").

${ }^{270}$ OECD, Is this Humanitarian Migration Crisis Different?, Migration Policy Debates, No. 7, Sept. 2015, available at http://www.oecd.org/migration/Is-this-refugee-crisis-different.pdf.

${ }^{271}$ Migrant Crisis: Greece, Croatia and Italy Face EU Legal Action, BBC, Dec. 10, 2015, available at http://www.bbc.com/news/world-europe-35064599.
} 
widely in their willingness to accept the migrants. ${ }^{272}$ Immigration was already a sensitive issue in Europe, with right-leaning anti-immigration policies making remarkable gains in recent years. It is thus unsurprising that the refugee crisis has produced vocal disagreements both within and among the EU's Member States, or that the EU's central instituions have commenced legal action to enforce various Member States' obligations in relation to the influx. ${ }^{273}$

Responding to the migrant crisis became considerably more difficult in November, when Islamic terrorists killed 130 people in Paris. ${ }^{274}$ Unsurprisingly, the attacks seemed to spur opposition across Europe to accepting more migrants, especially in light of concerns that some potential terrorists may be among the many thousands of Middle Eastern refugees. ${ }^{275}$ Moreover, the terrorist threat has brought pressure to revisit the Schengen Agreement, which abolished border controls among twenty-six European countries. ${ }^{276}$ Reinstituting permanent border controls, of course, would be a highly-visible marker making Europe more like an intergovernmental federation and less like a federal state.

I focus on the Euro crisis here, because it has been going on for longer and its effects on the EU's federal balance are thus somewhat easier to discern. But all

${ }^{272}$ See, e.g., Hungary Closes Border to Refugees as Turkey Questions EU Deal to Stem Crisis,
The Guardian, $\quad$ Oct. $16, \quad 2015, \quad$ available http://www.theguardian.com/world/2015/oct/17/hungary-closes-border-to-refugees-as-turkey-

questions-eu-deal-to-stem-crisis (recounting Hungary's efforts to block refugees); Europe's Migrant Acceptance Rates, The Economist, Sept. 1, 2015, available at http://www.economist.com/blogs/graphicdetail/2015/09/daily-chart (showing that rates range from over 300 migrants per 100,000 population in Sweden to a fraction of that in Hungary, Spain, and Poland).

273 See Migrant Crisis, supra note 271; Marcus Walker \& Anton Troianovski, Behind Angela Merkel's Open Door for Migrants, Wall Street Journal, Dec. 9, 2015, available at http://www.wsj.com/articles/behind-angela-merkels-open-door-for-migrants-1449712113; Bridge of Sneers, The Economist, Dec. 5, 2015, available at http://www.economist.com/news/europe/21679476-strange-spectacle-sweden-and-denmark-

sniping-each-others-immigration-policies-bridge (describing conflict between Denmark and Sweden over refuguee policy); Peter Teffer, French PM: Europe Can Receive No More Refugees, EUObserver, Nov. 25, 2015, available at https://euobserver.com/migration/131262 (reporting tensions among Member States on refugees).

${ }^{274}$ See Adam Nossiter \& Rick Gladstone, Paris Attacks Kill More than 100, Police Say; Border Controls Tightened, New York Times, Nov. 13, 2015.

${ }^{275}$ See, e.g., Anton Troianovski \& Marcus Walker, Paris Terror Attacks Transform Debate Over Europe's Migration Crisis, Wall St. Journal, Nov. 16, 2015, available at http://www.wsj.com/articles/paris-terror-attacks-transform-debate-over-europes-migration-crisis1447608944; Holly Ellyatt, After Paris, Is There a EU Backlash Against Migrants?, CNBC, Nov. 27, 2015, available at http://www.cnbc.com/2015/11/27/paris-attacks-turn-eu-leaders-againstmigrants.html.

276 See After Paris, Drawbridges Up? The Economist, Nov. 21, 2015, available at http://www.economist.com/news/europe/21678832-schengen-system-open-borders-was-alreadyunder-pressure-latest-terrorist-attacks-may (noting that "[c]alls to curb borderless travel were already growing louder" prior to the Paris attacks, and that a number of countries had already implemented limited border controls in response to the migrant crisis and prior terrorist incidents). 
three crises share one similar dynamic, which is that the EU has tended to respond intergovernmentally, with the discussion dominated by the most powerful member states-particularly Germany and France. The Euro area's effort to impose considerably stronger constraints on Member State fiscal policy, for example, paradoxically centralizes control over a critical area of governance while, at the same time, circumventing the EU's central political institutions in important ways. Likewise, national leaders have played the key roles on migration and terrorism. Although crises have tended to play a centralizing role in American federalism, they may also disrupt central institutions if those institutions are unable to lead the governmental response.

\section{Fiscal Federalism and Member State Sovereignty}

The Euro Crisis arose in part out of asymmetries between the various Member State economies in the euro area. Various aspects of the world financial crisis impacted different Member States differently. ${ }^{277}$ Because of their commitment to EMU, individual Member States like Greece lacked the ability to respond through monetary policy - a devaluation of the drachma, for example. ${ }^{278}$ They thus faced an increased risk of default on their debt, which gave rise to fears of contagion in other European Member States. That risk, and accompanying urges to bail out the most severeley affected States, put profound pressure on Europe's system of fiscal federalism.

The literature on fiscal federalism suggests that there are basically two ways to organize the financial relationship between a central government and its subunits. ${ }^{279}$ In most federal systems, the center guarantees the debts of the subunits. $^{280}$ These guarantees create a potential for moral hazard; subunits may spend and borrow willy nilly (and creditors will be willing to lend to them), knowing that the central government will make good their debts. In order to avoid that problem, most central governments retain control over fiscal policy by constraining the taxing, spending, and borrowing authority of subnational

\footnotetext{
${ }^{277}$ See, e.g., Pisani-Ferry, supra note 22, at 6-7; Van Overtveldt, supra note 22, at 80-94.

${ }^{278}$ See, e.g., Pisani-Ferry, supra note 22, at 87 (noting that "an important factor was that [Greece] was borrowing money in a currency that was its own, but over which it had no control"); Juan F. Navarro-Staicos, Greece Should Follow Argentina into Default and Devaluation, Christian Science Monitor, April 2, 2012, available at http://www.csmonitor.com/Commentary/Opinion/2012/0402/Greece-should-follow-Argentinainto-default-and-devaluation (noting that, in similar fiscal circumstances, Argentina defaulted on its debt and devalued its currency).

279 See generally Jonathan A. Rodden, Hamilton's Paradox: The Promise and Peril of Fiscal Federalism (2006); Michael S. Greve, Our Federalism Is Not Europe's. It's Becoming Argentina's, 7 Duke J. Con. L. \& Pub. Pol'y 17, 19 (2012).

280 See Paul E. Peterson \& Daniel Nadler, Freedom to Fail: The Keystone of American Federalism, 79 U. Chi. L. Rev. 253, 255 (2012) ("Except in Canada and Switzerland [and the U.S.], state debts in all federal systems in the industrialized countries of the world are implicitly or explicitly guaranteed by the federal government.").
} 
governments. ${ }^{281}$ The alternative viable arrangement is for the subunits to retain fiscal sovereignty over taxing, spending, and borrowing, while the central government ensures that the credit markets will discipline them by committing not to bail the subunits out in the event of a default. ${ }^{282}$ The trick, of course, is in making the no-bailout commitment credible. Where that effort succeeds, the costs of borrowing for each subunit-reflected in the interest rates it must pay on the bonds it issues-will vary according to the creditworthiness of each subnational government. ${ }^{283}$

The United States has generally pursued the latter arrangement. Federal law imposes no general constraints on state taxing, spending, or borrowing. The national government has, however, generally refused to bail out state governments when all that autonomy gets them into trouble. ${ }^{284}$ Eight states defaulted in the 1840 s, ten more in the late nineteenth century following Reconstruction, and Arkansas defaulted during the Depression. ${ }^{285}$ Hence when Charles Dickens referred to the worthlessness of "a United States security," he actually meant a bond issued by one of the American state governments that defaulted in the wake of the Panic of $1837 .{ }^{286}$ Although there have been efforts to get the national government to intervene in each instance, those efforts have generally been unsuccessful. ${ }^{287}$ The current significant differences among bond yields and credit ratings for the various American states strongly suggests that the financial markets continue to perceive the national government's "no bailout" commitment as highly credible. $^{288}$

Germany-the leading federal system within the EU-has chosen a mixed model; the central government controls taxation by the Lander but not

281 See Jonathan A. Rodden, Market Discipline and U.S. Federalism, in Peter Conti-Brown and David Skeel, eds., When States Go Broke: The Origins, Context, and Solutions for the American States in Fiscal Crisis 123, 128 (2012); Peterson \& Nadler, supra note 280, at 254-55; Greve, Our Federalism, supra note 279, at 19.

282 See Rodden, Market Discipline, supra note 281, at 128; Peterson \& Nadler, supra note 280, at 255-56.

${ }^{283}$ See Rodden, Market Discipline, supra note 281, at 137 (collecting data on credit-default swaps on state debt obligations).

${ }^{284}$ Unlike in the EU, the United States has no formal prohibition of bailouts. The credibility of the American "no bailout" commitment rests instead on historical experience, in which the U.S. government has proven willing to let states default without a federal rescue. See Michael S. Greve, The Upside Down Constitution 168-69 (2012).

285 See Peterson \& Nadler, supra note 280, at 266-67.

${ }^{286}$ See John V. Orth, State Debts \& Federal Jurisdiction, 7 Duke J. Con. L. \& Pub. Pol'y 1, 1-2 (2012) (discussing Dickens's novel, A Christmas Carol).

${ }^{287}$ See Rodden, Hamilton's Paradox, supra note 279, at 57-64.

288 See Rodden, Market Discipline, supra note 281, at 137-40; see also Pamela M. Prah, Adam Rotmil, \& Stephen C. Fehr, Infographic: S\&P State Credit Ratings, 2001-2014, Stateline, June 9, 2014, available at http://www.pewtrusts.org/en/research-andanalysis/blogs/stateline/2014/06/09/sp-ratings-2014 (showing the variation over time in state credit ratings from Standard \& Poor's). 
expenditures or borrowing, and bailouts are available but not automatic. ${ }^{289}$ Because of the strong bailout expectation, the credit ratings of the various Lander do not vary according to actual creditworthiness of the particular Lander governments. ${ }^{290}$ But the EU itself purports to follow the American model of fiscal federalism. The Member States do their own taxing, spending, and borrowing, and Brussels does not formally guarantee their debts. Indeed, the Treaty of Lisbon incorporated an explicit "no bailout" clause. ${ }^{291}$ Prior to the Euro crisis, the Union did impose some fiscal constraints on the Euro-zone countries in the form of the "Stability and Growth Pact," but those constraints quickly lost most of their credibility when the Union failed to enforce them after French and German violations of the Pact's deficit limits. ${ }^{292}$ Nonetheless, financial markets appear to have treated the various Member States' debts as if they were part of a fiscallyunitary federation. ${ }^{293}$

Nothing in these fiscal or monetary arrangements can be said to have caused the Euro crisis. The trouble was that the various Euro-zone countries varied considerably in their vulnerability to the worldwide financial crisis that began in 2007, and the EU lacked the central stabilization mechanisms available to more centralized states. ${ }^{294}$ In particular, countries like Greece, Portugal, and Ireland-which generally had less competitive economies and more profligate public sectors-suddenly found themselves in danger of defaulting on their debts. What the euro arrangement did do was to call the EU's no bailout commitment into question, ${ }^{295}$ because an actual debt default by a Euro-zone country would put pressure on that Member State to exit the Euro so as to regain the monetary tools to respond to the crisis. Moreover, the integration of the Euro-zone economies meant that much of the Greek debt, as well as debt issued by other struggling Member States, was held by banks in Germany and other powerful EU

\footnotetext{
${ }^{289}$ See Rodden, Hamilton's Paradox, supra note 279, at 153-87.

290 See, e.g., UniCredit, Handbook of German States 3 (2012) (stating that "[a]11 16 [German] states enjoy credit ratings in the highest rating category" and attributing this to "the federal solidarity principle... guaranteeing support to states should they ever be in real financial difficulties").

${ }^{291}$ Consolidated Treaty on the Functioning of the European Union, art. 125, 2010 O.J. (C 83/99) (ex 103 TEC)

${ }^{292}$ See, e.g., The Death of the Stability Pact? The Economist, Nov. 27, 2003, available at http://www.economist.com/node/2246457; see also Pisani-Ferry, supra note 22, at 31.

${ }^{293}$ See, e.g., Greve, Our Federalism, supra note 279, at 21; Van Overtveldt, supra note 22, at 85 (noting that prior to the crisis, "[t]he spread between Greek and German bonds almost disappeared").

${ }^{294}$ See Ziblatt, supra note 144 , at 115.

${ }^{295}$ See Pisani-Ferry, supra note 22, at 69 ("[I]nvestors believed that in the unlikely event of an accident, euro-area member states would put together some type of rescue operation. . . [T] did not see the so-called no-bailout clause as credible enough to fully price the risk of individual sovereign default.").
} 
countries. ${ }^{296}$ Under the circumstances, it is not altogether surprising that the nobailout pledge went by the boards. ${ }^{297}$

It is not obvious, in fact, whether the U.S. model of fiscal federalism, predicated on a credible no-bailout commitment, is viable in a modern economy with extensive and highly-integrated governmental establishments. ${ }^{298}$ During the financial crisis of 2008-09, the United States government bailed out multiple large private actors, including major banks, insurance companies, and automobile manufacturers-on the ground that their collapse would cause catastrophic systemic damage to the American economy. ${ }^{299}$ It is hard to believe that a default by, say, California or Illinois would not cause comparable risks. ${ }^{300}$ Indeed, the U.S. territory of Puerto Rico is teetering toward default as this chapter goes to press, and prominent voices are already arguing that "Puerto Rico is "too big to fail."

Two related aspects of modern "cooperative federalism" further increase the likelihood that the national government would consider any American state "too big to fail." The first is that, because most cooperative federalism programs involve a combination of federal and state spending on some sort of "matching" formula, much state spending is driven by federal spending choices. It might accordingly seem unfair not to bail out a state government whose profligacy was

\footnotetext{
${ }^{296}$ On the further complications caused by retention of responsibility for banking regulation by the Member States, see Pisani-Ferry, supra note 22, at 144-50.

${ }^{297}$ See Hinarejos, supra note 266, at 1628 (suggesting that allowing Greece and other troubled Member States to default could "have had fatal consequences for the future of the EU as a political project"). The measures addressing the debt crisis were not technically a "bailout," and the ECJ has held that they did not violate the no-bailout clause in the Treaty. See Case No. D370/12, Pringle v. Government of Ireland, Nov. 27, 2012. But as a practical matter, most observers seem to view these measures as bailouts. See Hinarejos, supra note 266, at 1629; From Bail-out to Bail-in, The Economist, Dec. 14, 2013, available at http://www.economist.com/blogs/freeexchange/2013/12/european-banks.

${ }^{298}$ See Emily D. Johnson \& Ernest A. Young, The Constitutional Law of State Debt, 7 Duke J. Con. L. \& Pub. Pol'y 117, 147-48 (2012).

${ }^{299}$ See generally Andrew Ross Sorkin, Too Big to Fail (2009) (telling the story of the Wall Street bailouts).

300 See Svea Herbst-Bayliss \& Jonathan Stempel, Buffett: US Can Bail Out States, Insurers Pained, Reuters, May 1, 2010, available at http://www.reuters.com/article/2010/ 05/01/berkshire buffett-ratings-idUSN0118355720100501 (reporting statement by uber-investor Warren Buffett that "it would be very hard, in the end, for the federal government to turn away a state that is having extreme financial difficulties when in effect it honored [the debts of] General Motors and various other entities"); Johnson \& Young, supra note 298, at 136 (making a similar point). On the other hand, as Michael Greve has pointed out, most American sovereign debt is held by individuals and pension funds - not the large banks that held most of the EU's Member State debt. Hence, the risk of a State's default bringing down the financial system (and thus the pressure to prevent it through a bailout) is considerably lower in the U.S. See Greve, Our Federalism, supra note 279, at 21-22.

${ }^{301}$ See Michelle Wilde anderson, Let the U.S. Treasury Rescue Puerto Rico, New York Times, Dec. 6, 2015, available at http://www.nytimes.com/2015/12/07/opinion/international/let-the-ustreasury-rescue-puerto-rico.html?_r=0.
} 
in part dictated by decisions made in Washington, D.C. ${ }^{302}$ The second, converse point is that because the federal government typically depends on state officials to implement many of its regulatory and benefit schemes, the federal government simply cannot allow those state governments to collapse or even seriously cut back on their governmental capacity. ${ }^{303}$ State creditors appear to nonetheless assume that no rescue would be forthcoming in the event of a state default, but it is no longer clear that that assumption is warranted.

The same factors undermining the likelihood that the United States would refuse to bail out a state government seem fully applicable-if not more applicable-to Europe. Given that the European law currently leaves social provision largely to the Member States, it may be that a smaller percentage of Member State spending is driven by EU requirements than in the United States. But the EU is almost completely dependent on the Member States for enforcement of the regulatory law that Brussels does produce. If any Member State found itself in an existential financial crisis, a severe contraction in its governmental capacity might well undermine implementation of European law to a degree unacceptable either to Brussels or to the Member States. ${ }^{304}$ To be sure, EMU adds another layer of interdependence. But it may be that the EU has not had to confront the possibility of bailing out a non-Eurozone state simply because those states have tended to be in better fiscal shape of late-not because the non-Euro-zone is insufficiently integrated to raise similar systemic risks if such a state should get into trouble.

If the fiscal autonomy/no-bailout model is on the wane, then the EU will need to consider exercising greater control over Member States' fiscal policy in order to avoid the moral hazard problem. This would not necessarily require the EU to assume broad powers over taxing and spending. As Alicia Hinarejos points out, the EU would have a choice between a "surveillance model', where Member States coninue to maintain all taxing power and where the EU has a corrective role as an enforcer of discipline," and a "classic fiscal federalism model', where the EU acquires taxing power and its own independent sphere of fiscal authority, and thus its own fiscal tools for macroeconomic stabilization." 305 The recent "Fiscal Compact,"306 concluded among the Eurozone members in 2012, fits into the surveillance model. Its primary innovation is to require the signatory states "to enact the so-called 'golden rule' — a requirement that annual government budgets

\footnotetext{
${ }^{302}$ See Johnson \& Young, supra note 298, at 148; Greve, Our Federalism, supra note 279, at 2632.

${ }^{303}$ See Johnson \& Young, supra note 298, at 148; Greve, Our Federalism, supra note 279, at 39 (suggesting that absent reform of the system, we will see "an accelerating series of increasingly aggressive bailouts-by-any-other-name" in the U.S.).

${ }^{304}$ Cf. Ziblatt, supra note 144, at 115-22 (suggesting that federations tend to centralize authority were the government capacity of subnational units is weak).

${ }^{305}$ Hinarejos, supra note 266, at 1621.

${ }^{306}$ Treaty on Stability, Coordination and Governance in the Economic and Monetary Union, Mar. 2, 2012, available at http://european-council.europa.eu/media/639235/st00tscg26_en12.pdf.
} 
be balanced-in Member State constitutions."307 This requirement is to be enforced not only by conditioning financial assistance under the European Stability Mechanism (ESM), but also through a judicial enforcement provision under which any other party to the Compact may bring a state's noncompliance before the ECJ. ${ }^{308}$

In one sense, the Fiscal Compact brings European fiscal federalism closer to the American model. After all, almost all of the American states have balanced budget requirements, and those requirements (with some allowance for creative bookkeeping) are generally observed. ${ }^{309}$ But America's "golden rules" were adopted autonomously by the States; they remain entirely creatures of state law, and there are no federal constraints on state budgeting analogous to the Fiscal Compact. ${ }^{310}$ It seems unlikely, moreover, that any federal court would ever be willing to enforce compliance with a State's balanced budget rule. ${ }^{311}$ The result, as Federico Fabbrini has observed, is a "paradox": "[W]hile EU member states have willingly refused to embrace a U.S.-like federal model for the governance of the Euro-zone on the assumption that this was too restrictive of state sovereignty, they have established a regime which is much less respectful of state fiscal sovereignty than the U.S. one." 312

The Fiscal Compact thus illustrates Alicia Hinarejos's point that the surveillance model, although adopted as a less intrusive option than a wholesale shift of fiscal powers to the EU, may be "just as problematic from the point of view of democratic legitimacy, and as threatening to national autonomy," as the classic fiscal federalism model. ${ }^{313}$ If EU surveillance of Member State budgets relies primarily on "soft law," as it did under the Stability and Growth Pact, then it is likely to prove toothless. The Fiscal Compact ratchets up both the specificity of the budgetary requirements and the enforcement mechanisms, but it does not yet require specific taxing and spending policies to meet the Compact's fiscal targets.

${ }^{307}$ Federico Fabbrini, The Fiscal Compact, The "Golden Rule," and the Paradox of European Federalism, 36 B.C. Int'l \& Comp. L. Rev. 1, 2 (2013).

${ }^{308}$ See id. at 7-9.

${ }^{309}$ See Greve, Our Federalism, supra note 279, at 19-20.

${ }^{310}$ See Ziblatt, supra note 144, at 124.

${ }^{311}$ It is not clear that such a case could even get into federal court, given the various obstacles posed by standing and abstention doctrines, state sovereign immunity, and the possibility that the cae would pose a nonjusticiable political question.

${ }^{312}$ F. Fabbrini, Fiscal Compact, supra note 307, at 32-33. Professor Fabbrini also points out another important difference between the American structure and the European one after the Fiscal Compact. Although the American states' balanced budget requirements generally keep them from engaging in counter-cylical fiscal policy, the federal government is (spectacularly) not bound by similar constraints; hence, it has powerful counter-cylical tools. Nothing comparable exists at the EU level. Whether that is a good idea is outside the scope of this article.

${ }^{313}$ Hinarejos, supra note 266, at 1638-39; see also F. Fabbrini, Fiscal Compact, supra note 307, at 4 . 
Some observers, however, believe that this may be the next step if the present Compact fails to ensure fiscal discipline. ${ }^{314}$

In any event, even the current level of control seems problematic from a democratic perspective. As the often-messy American debates over the last year concerning the national debt ceiling, spending cuts, and other financial measures make clear, ${ }^{315}$ fiscal questions lie at the heart of contemporary democratic politics. Moreover, debt assistance to Greece and other Member States has come attached to draconian austerity conditions that both critically undermine each State's autonomy and also engender significant hostility to European institutions. Daniel Ziblatt argues that these arrangements are not simply a more centralized form of federalism, but rather a form of direct rule by European actors like the ECB. ${ }^{316}$ These developments have led Fritz Scharpf to conclude that "[a]s long as the present euro regime continues, democracy has no chance in Europe." 317

Recent litigation in Germany has moved these democratic concerns into the courts. The German Federal Constitutional Court has interpreted the German Basic Law to require national parliamentary control of basic governmental decisions, including basic fiscal powers. ${ }^{318}$ In the Gauweiler litigation, the GFCC challenged the European Central Bank's "Outright Monetary Transactions" program (OMT), under which the ECB sought to resolve the various Member State debt crises by promising to buy an unlimited amount of government-issued bonds in the secondary market. The GFCC declined to enjoin the OMT program and referred the case to the ECJ, but it strongly suggested that if construed broadly, the OMT program would violate the ECB's mandate under the European treaties and possibly the German Basic Law's requirements for democratic decisionmaking as well. ${ }^{319}$ When the ECJ ruled on the Gauweiler reference in June of 2015, however, it upheld the OMT program's validity. ${ }^{320}$ Although the ECJ did require that

\footnotetext{
${ }^{314}$ See, e.g. Hinarejos, supra note 266, at 1634-35; see also Luca Prete, Some Brief Comments on the Procedures of Enforcement of the Fiscal Compact, One Year After its Entry into Force, 2015 Eur. L. Reptr. 81, 87-90 (expressing doubt whether the Fiscal Compact actually guarantees effective enforcement of budgetary discipline).

315 See, e.g., Zachary Goldfarb, Focus Shifts to Looming Debt Ceiling Deadline as Shutdown Talks at White House Go Nowhere, Washington Post, Oct. 2, 2013, available at http://www.washingtonpost.com/politics/obama-cancels-part-of-asia-trip-washington-braces-forprolonged-budget-battle/2013/10/02/e035be98-2b4b-11e3-8ade-a1f23cda135e_story.html.
}

${ }^{316}$ See Ziblatt, supra note 144, at 122-29.

${ }^{317}$ Fritz W. Scharpf, After the Crash: A Multilevel European Democracy, in Van Middelaar \& Van Parijs, supra note 173, at 139, 144.

${ }^{318}$ See Lisbon Treaty Case, BVerfGE 123, 267 (343); see also EFSF Case, BVerfGE 129, 124 (178) ("As representatives of the people, the elected Members of the German Bundestag must retain control of fundamental budgetary decisions even in a system of intergovernmental administration."); Miller, supra note 7, at 17.

${ }^{319}$ See https://www.bundesverfassungsgericht.de/pressemitteilungen/bvg14-009en.html.

${ }^{320}$ See Case C-62/14, Gauweiler v. Deutscher Bundestag [2015], ECLI:EU:C:2015:400. The ECJ rejected arguments that the policy crossed the line between monetary and economic policy (the latter of which falls outside the ECB's mandate), was not proportionate, and violated the bailout 
safeguards be built into any exercise of the OMT authority, "these safeguards are not new or especially onerous, and they do not go as far as the ones put forward by the German Federal Constitutional Court as conditions of legality." 321 Although the ECJ's decision may well end jockeying over the OMT program-which has not, in fact, yet been implemented-it seems unlikely to resolve broader concerns about the legality or legitimacy of the Euro area's response to the crisis.

More broadly, the Euro area-and the EU generally-faces difficult choices concerning whether to further combine economic prerogatives in order to shape a more unified economic policy, or whether to try to stabilize the system on an intergovernmental basis. As early as 1999, Francis Snyder argued that "[t]he debate about EMU ... is a debate about the future of the EU as a polity, the European social model, and the nature of European identity." 322 The GFCC's more recent disquiet about efforts to maintain the EMU is a signal that the Euro crisis has brought the EU to the limits of its intergovernmental model. ${ }^{323}$ Hence, as Jean Pisani-Ferry has observed, "beyond the immediate macroeconomic and financial urgencies, the euro area is confronted with deeper choices about the type of economy it wants and the degree to which it is willing to accept the political consequences of its economic choices." 324

\section{Variable Geometry and Intergovernmentalism}

A further complication arises from the EU's "variable geometry"- that is, the frequently asymmetrical character of its federalism. Only nineteen of the EU's twenty-eight members currently use the Euro, although several more are seeking to meet the euro zone's eligibility critiera. ${ }^{325}$ Several non-Eurozone countries signed the Fiscal Compact, reflecting the degree of fiscal interdependence in Europe even apart from the Euro. But the United Kingdom, Croatia, and the Czech Republic are

prohibition in the EU treaties. See generally Alica Hinarejos, Saving the Single Currency? Gauweiler and the Legality of the OMT Programme, EU Law Analysis, June 17, 2015, http://eulawanalysis.blogspot.com/2015/06/saving-single-currency-gauweiler-and.html.

${ }^{321}$ Hinarejos, Gauweiler, supra note 320.

${ }^{322}$ Francis Snyder, EMU Revisited: Are We Making a Constitution? What Constitution Are We Making? In Craig \& De Burca, supra note 35, at 417, 418.

323 See, e.g., Peter Lindseth, Barking vs. Biting: Understanding the German Constitutional Court's OMT Reference . . And Its Implications for EU Reform, eutopia law, Feb. 10, 2014, $\mathrm{http}$ ///eutopialaw.com/2014/02/10/barking-vs-biting-understanding-the-german-constitutionalcourts-omt-reference-and-its-implications-for-eu-reform/ (suggesting that addressing the GFCC's concerns will require a more democratic fiscal process at the EU level, which will in turn require deepening the Union); Kuper, supra note 185 ("During the economic crisis, the EU has been morphing into something of a federal state: central control over national budgets, European bailouts, perhaps banking union."); Pisani-Ferry, supra note 22, at 142 (observing that an "agglomeration model" raises difficult problems of "political and social acceptability," while a "rebalancing model" that would seek to minimize further integration raises "questions of economic viability").

${ }^{324}$ Id. at 143.

${ }^{325}$ See The Euro, Europa, http://europa.eu/about-eu/basic-information/money/euro/index_en.htm (visited Dec. 18, 2015). 
not signatories. ${ }^{326}$ Moreover, the Euro zone has imposed different - and often quite draconian-policies on particular Member States as a condition of collective assistance. ${ }^{327}$ The Euro crisis and its accompanying fiscal reform thus implicate different groups of countries and to varying degrees. And they have been adopted and implemented through channels apart from the EU's political institutions. It has always been unclear whether and to what extent variable geometry threatens the cohesion and stability of the European legal order. To the extent that the EU fundamentally reshapes its model of fiscal federalism in ways that leave out significant players, sideline established institutions, and impose asymmetrical and unpopular burdens, those tensions are only likely to increase. ${ }^{328}$

The EU's "variable geometry" is not inherently antithetical to a federal regime. ${ }^{329}$ Canada has long survived with special accommodations for Francophone Quebec, and even the United States has tolerated certain asymmetries among the states, such as the special autonomy granted to California to set demanding air pollution standards. ${ }^{330}$ In some circumstances, the Europe a la carte approach may defuse otherwise intractable political conflicts among the Member States.

The politics of the Euro crisis, however, have exposed an important possible weakness in the EU's variable approach. Because key Member States remain outside the Euro, the crisis has been handled intergovernmentally, outside "the complex institutional system designed since the Treaty of Rome, in which multiple checks and balances made sure that no group of states, or citizens, could systematically dominate over the others in the decision-making process." ${ }^{3} 1$ Federico Fabbrini thus argues that this intergovernmental approach has given free

${ }^{326}$ See Thomas Beukers \& Marijn Van der Sluis, The Variable Geometry of the Euro-Crisis: A
Look at the Non-Euro Area Member States, EUI Dept. of Law Research Paper no. 2015/33 (2015),
at 4, available at http://papers.ssrn.com/sol3/papers.cfm?abstract_id=2616717.

${ }^{327}$ See Federico Fabbrini, States' Equality v States' Power: the Euro-crisis, Inter-state Relations and the Paradox of Domination, 17 Cambridge Yearbook of Euro. Leg. Stud. 3, 13-14 (2015); Ziblatt, supra note 144, at 127.

${ }^{328}$ I do not mean to imply any sort of view on the substantive merits of the various austerity policies imposed in the wake of the euro crisis. If anything, I am inclined to be sympathetic to the aims of those policies. But there is no doubt that they raise significant structural and democratic difficulties.

${ }^{329}$ See, e.g., Elena Griglio \& Nicola Lupo, Towards an Asymmetric European Union, Without an Asymmetric European Parliament, (June 20, 2014), LUISS Guido Carli School of Government Working Paper No. SOG-WP20/2014, available at http://ssrn.com/abstract=2460126.

${ }^{330}$ See 42 U.S.C. $§ 7543($ b). California is the only state that qualifies for a waiver of federal preemption under this provision, due to its early adoption of air pollution controls.

${ }^{331}$ F. Fabbrini, States' Equality, supra note 327, at 33; see also Pisani-Ferry, supra note 22, at 167-73 (describing how the response to the euro crisis has skirted the "federal" model, which would have worked through the EU's political institutions, in favor of a "mutual assistance" model based on intergovernmental actions by particular states); Van Overtveldt, supra note 22, at 166 (arguing that the intergovernmental approach to the crisis "does not improve trust in or the credibility of the European institutions"). 
rein to political and economic power imbalances among the Member States, with the result that Germany "has taken over as the hegemonic player." 332 This tendency highlights not only the dangers of variable geometry but also the "paradox" that, although intergovernmentalism is traditionally viewed as a guarantee of state equality, it may under the right circumstances press in the opposite directions.

The American states likewise differ significantly in size, prosperity, and political clout. It may thus be of interest to think about why one rarely hears analogous complaints that a single state-or even a coalition of large ones-is dominating American politics. ${ }^{333}$ This is no doubt partly attributable to the greater number of players (50 rather than 28) and the somewhat smaller percentages of population and economic output that the largest American states represent. ${ }^{334}$ But the numbers are not radically different. The more important difference may stem from the concentration of government capacity at the center in the U.S. federalist system, as compared to the EU's intergovernmental maintenance of primary budgetary and bureaucratic competences at the Member State level.

Because of the predominance of national governance in the United States, even very large states have a hard time exerting power directly on the national stage; state power, instead, tends to flow from a state's ability to influence the national government itself. ${ }^{335}$ And while the structure of Congress does build in greater representation for large states, the more important struggle is often for

\footnotetext{
${ }^{332}$ F. Fabbrini, States' Equality, supra note 327, at 13. Concerns about German "hegemony" are widespread. See, e.g., Zanny Minton Beddoes, Europe's Reluctant Hegemon, The Economist, June 15, 2013, available at http://www.economist.com/news/special-report/21579140-germanynow-dominant-country-europe-needs-rethink-way-it-sees-itself-and (observing that "across a large swathe of European policy, Germany has become much more than a first among equals"); Van Overtveldt, supra note 22, at 167 (Germany is "both dominant and disliked in Europe"); Marder, supra note 108, at 96 (arguing, from the Left, that "political inequalities within the Union have grown to unsustainable levels").

${ }^{333}$ The American malady has historically been sectionalism-that is, conflict between coalitions of states grouped by geographic region. See Frederick Jackson Turner, The Significance of Sections in American History (1932). In more recent years, the difficulty has been political polarization, which does not always track state lines, see, e.g., Bishop, supra note 176, and when it does tends to transcend regional politics, see, e.g., Andrew Gelman, Red State, Blue State, Rich State, Poor State: Why Americans Vote the Way They Do (2009).

${ }^{334}$ In 2014, for example, the three largest state economies, California, Texas, and New York, represented 13 percent, 9 percent, and 8 percent of U.S. national GDP, respectively. See U.S. Dept. of Commerce, Bureau of Economic Analysis, Broad Growth Across States in 2014, June 10, 2015, Table 1, available at https://www.bea.gov/newsreleases/regional/gdp_state/2015/pdf/gsp0615.pdf. In the same year, the three largest EU economies, Germany, the United Kingdom, and France, represented 21 percent, 16 percent, and 15 percent of EU GDP, respectively. See Eurostat, National Accounts and GDP, May 2015, Table 1, available at http://ec.europa.eu/eurostat/statisticsexplained/index.php/National_accounts and_GDP. The three largest U.S. states thus account for only 30 percent of the national economy, while the three largest EU members account for just over 50 percent of the Union's.

${ }^{335}$ See, e.g., Wechsler, supra note 130; Baker \& Young, supra note 128, at 117-28..
} 
control of the Presidency and, with it, control of the national bureaucracy. That contest is, of course, a matter of competition between two national political parties; to the extent that states derive power from this competition, that power tends to flow to the swing states that determine the outcome of presidential elections. None of the three largest states (by population and economic output) California, Texas, and New York-is a swing state, and thus these states are largely ignored in presidential campaigns (except for the not-inconsequential function of fundraising). The dynamic of swing state power-conferring leverage on the next tier of states, such as Florida, Ohio, Pennsylvania, and Virginia - thus cuts against the clout of the largest states. ${ }^{336}$ And the organization of the Congress-especially its reliance on powerful committees often run by senioritycreates yet another power dynamic that may confer disproportionate leverage on small states like West Virginia or Wisconsin. ${ }^{337}$

All of this tends to confirm Professor Fabbrini's point that intergovernmentalism is not always good for state equality, because when states interact as states, the power disparities between them will often prove influential. In America, the constitutional separation of powers at the national level tends to check and balance the power that any given state can exercise over national policy. ${ }^{338}$ Likewise, as Fabbrini points out, the EU's complex institutional architecture tends, when the EU acts supranationally, to dilute power disparities among the Member States. ${ }^{339}$ But if crises prompt Europeans to look first to their Member States, which then cooperate on an intergovernmental basis, these power dispoarities will tell upon the results.

The broader trouble with variable geometry, however, is that as the Euro (or Schengen) areas become more economically and legally distinct from the rest of the EU, they will come to need more fully developed governments of their own. ${ }^{340}$ The closest American analog to variable geometry-the interstate

${ }^{336}$ See, e.g., Chris Cilizza \& Aaron Blake, The 10 Closest States in Election 2012, Wash. Post, Nov. 8, 2012, available at https://www.washingtonpost.com/news/the-fix/wp/2012/11/08/the-10closest-states-in-election-2012/ (listing Florida, Ohio, North Carolina, Virginia, Colorado, Pennsylvania, Iowa, New Hampshire, Nevada, and Wisconsin as likely swing states in future presidential elections).

337 The last 10 presidents pro tempore of the Senate, for example, were from Utah, Vermont, Hawaii, West Virginia, Alaska, and South Carolina. See U.S. Senate, President Pro Tempore, http://www.senate.gov/artandhistory/history/common/briefing/President_Pro_Tempore.htm\#5

(visited Dec. 15, 2015). Of the last 10 Speakers of the House of Representatives, two each were from Massachusetts and Texas, with the others hailing from Oklahoma, Washington, Georgia, Illinois, California, Ohio, and Wisconsin. See U.S. House of Representatives, List of Speakers of the House, http://history.house.gov/People/Office/Speakers-List/ (visited Dec. 15, 2015).

${ }^{338}$ See, e.g., Federalist No. 51, at 321 (James Madison) (Isaac Kramnick ed., 1987) (1788) (noting that separation of powers complements federalism as part of a "double security" for liberty).

${ }^{339}$ See F. Fabbrini, States' Equality, supra note 327, at 4-8.

${ }^{340}$ See, e.g., Pisani-Ferry, supra note 22, at 165 ("The euro area is of course not equipped with a government, but with a series of partial powers."). 
compact-is typically limited to matters of an extremely narrow scope. ${ }^{341}$ EMU and, to a somewhat lesser extent, Schengen create significant divergences in interests and imperatives with respect to monetary and fiscal policy and border security, respectively. In effect, part of the EU has chosen a more centralized model for these issues, while the remainder has chosen to stick with an intergovernmental approach. ${ }^{342}$ But the "closer union" of the euro and Schengen areas has relied primarily on freestanding rules or ad hoc international agreements without creating actual governing institutions. It is not at all clear whether this uneasy compromise can withstand the pressures generated by the euro, migration, and terror crises of recent years. As Jean Pisani-Ferry has pointed out, "[g]overnance by rules and procedures can work fine in fair-weather conditions, but it cannot be relied on in stormy weather." 343

\section{Conclusion}

Jean Monnet said that Europe "would be forged in crises, and would be the sum of the solutions to these crises." 344 As this essay goes to press, all three of the crises considered here-concerning the euro, migration and refugees, and terrorism-continue to play out in real time. ${ }^{345}$ These crises raise basic questions of constitutional structure, whether or not Europeans are ready to look past the daily headlines and confront them as such. In each case, the EU's uneasy compromise between federalism and intergovernmentalism may impede a stable solution-or the need for a solution may undermine that compromise, prompting a sharp move toward one or the other model.

Any firm prediction about ultimate outcomes for these crises deserves to be met with healthy skepticism. As Christian Joerges has written, "the development of an ever closer and then ever more democratic Europe can no longer be taken for granted." ${ }^{446}$ It is worth remembering, however, that "predictions of the EU's demise are not new." ${ }^{347}$ Neither are warnings of impending consolidation. So far, both the federal and intergovernmental elements of the EU's architecture have

\footnotetext{
${ }^{341}$ American interstate compacts, authorized by Art. I, $\S 10$ of the Constitution, typically create joint agencies to manage a common resource, such as the Colorado River Compact or the Atlantic Marine Fisheries Commission, or manage local public functions and infrastructure in an area that stradles state lines, such as the New York-New Jersey Port Authority.

${ }^{342}$ See, e.g., Pisani-Ferry, supra note 22, at 173 ("As things stand, Europe is caught between its current preference for intergovernmental arrangements and the implicit federal chracter of the project it has embarked on when creating the euro.").

${ }^{343}$ Pisani-Ferry, supra note 22, at 167.

344 Jean Monnet, Mémoires (1976), quoted in Pisani-Ferry, supra note 22, at 18.

${ }^{345}$ Moreover, a possible fourth crisis, prompted by British secession from the EU, looms on the horizon. See Battling with Britain, The Economist, Dec. 12, 2015, available at http://www.economist.com/news/europe/21679839-eu-faces-many-crises-one-them-unlike-allrest-battling-britain.

${ }^{346}$ Joerges, supra note 71 , at 75.

${ }^{347}$ Kelemen, Durability, supra note 27 , at 51.
} 
proven quite enduring. As Europe moves forward, the experience of other federal systems will continue to provide valuable lessons - and cautionary tales. The growing awareness of European federalism among American public lawyers has enriched debates within the United States simply by reminding us that many things we take for granted-e.g., a federal system's need for a common foreign policy and a single supreme tribunal-are not eternal verities but simply contingent characteristics of our own system. Hopefully certain aspects of the American experience - such as the indeterminacy of textual limits on enumerated central power, or the potential of "private attorneys general" to offset constraints on the central government's enforcement resources - will be similarly useful in Europe.

As these examples suggest, comparative experience is more likely to undermine longstanding assumptions than to provide off-the-shelf answers to common problems. The present circumstances and historical arcs of Europe and America are simply too different to import concepts and policies from one context to the other. But if, as Socrates suggested, the wise man knows what he does not know, ${ }^{348}$ then comparative law may be a path to wisdom. As I hope to have demonstrated here, the real value of comparative work resides not in the answers it provides but in the questions it provokes.

\footnotetext{
${ }^{348}$ Plato, Apology, in The Last Days of Socrates 39, 44-45 (Hugh Tredennick \& Harold Tarrant, trans. 1954).
} 